\title{
Matematik Öğretmenlerinin Ders İmecesi Kapsamında Köklü İfadelerin Öğretimine İlişkin Oluşturdukları Ders Planı*
}

\section{The Mathematics Teachers' Lesson Plan Related to Teaching Radical Expressions During the Lesson Study*}

\author{
Aytuğ ÖZALTUN ÇELiK**, Esra BUKOVA GÜZEL***
}

\begin{abstract}
Öz: Bu çalışmanın amacı, öğrenci düşüncesi bilgisinin gelişimine yönelik ders imecesi döngüsüne katılan üç matematik öğretmeninin köklü ifadelerin öğretimine ilişkin geliştirdikleri ders planlarını incelemektir. Durum çalışması desenine dayalı gerçekleştirilen çalışmanın katılımcılarını bir lisede görev yapmakta olan üç matematik öğretmeni oluşturmuştur. Çalışmanın verileri ders imecesinin ilk döngüsü kapsamındaki öğretmenlerin planlama ve revizyon toplantılarındaki grup görüşmeleri, iki saati araştırma dersi ve iki saati revizyon dersi olmak üzere dört saatlik derslere ilişkin hazırlanan ders planları, bu derslere yönelik gözlemler ve öğretmenlerin yansıtıcı günlükleridir. Veriler betimsel analiz yöntemiyle ders planının giriş, geçiş-geliştirme ve kapanış aşamaları bağlamında analiz edilmiştir. Öğretmenler, araştırmacılar tarafindan alan yazından yararlanılarak hazırlanan öğrenci düşüncelerine odaklanmaya yönelten ders planı kılavuzunu kullanarak köklü ifadelerin öğretimine ilişkin bir ders planı hazırlamışlardır. Bir öğretmenin hazırlanan planı araştırma dersinde uygulaması ve diğer öğretmenlerin ve araştırmacıların öğrencilere odaklanarak dersi gözlemlemesi sonrasında yapılan yansıtmalarla plan gözden geçirilmiş ve geliştirilmiştir. Geliştirilen planın ders imecesinin revizyon dersinde uygulanmasından sonra yapılan yansıtma ve geliştirme sürecinde plan üzerinde yeni düzeltmeler yapılıp köklü ifadelerin öğretimine ilişkin nihai bir plan ortaya koyulmuştur. Ortaya koyulan ders planının hem köklü ifadelerin öğretiminde hem de öğrenci düşüncelerine odaklanan bir dersin planlanmasında matematik öğretmenlerine ve araştırmacılara yol gösterici olacağ düşünülmektedir.
\end{abstract}

Anahtar Kelimeler: Ders imecesi, ders planı, köklü ifadeler, matematik öğretmenleri, öğrenci düşüncesi bilgisi

\begin{abstract}
The purpose of this study is to examine the lesson plans related to teaching the radical expressions developed by the three mathematics teachers who participated in a lesson study for improving their knowledge of student thinking. The participants of the study which was a case study design were three mathematics teachers working in a high school. The data were collected from the group discussions in the planning and revision meetings, the lesson plans of the two-hour research lessons and the two-hour revision lessons, the observations of these lessons and the teachers' reflective diaries in the scope of the first cycle of the lesson study. The data were analyzed by using descriptive analysis in the context of the lesson plan's segments of getting started, working on it and closure. The teachers prepared a lesson plan for teaching radical expressions by using the lesson plan guide which enabled to focus on the students' thinking prepared by using the literature. The plan was revised and improved by the reflections made after one of the teachers implemented the plan in the research lesson and other teachers and the researchers observed the lesson by focusing on the students' thinking. The revised plan was implemented, then the new necessary changes were discussed at the reflection and improvement meetings and the final plan about teaching the radial expressions was designed. It is thought that the lesson plan will be guide for mathematics teachers and researchers in both teaching the radical expressions and planning a lesson focused on students' thinking. Keywords: Lesson study, lesson plan, radical expressions, mathematics teachers, knowledge of student thinking
\end{abstract}

\footnotetext{
*Bu çalışma Doç. Dr. Esra Bukova Güzel danışmanlığında yürütülen Arş. Gör. Aytuğ Özaltun Çelik'in "Matematik Öğretmenlerinin Mesleki Gelişimleri: Öğrenci Düşüncesi Bilgisinin Öğretime Yansıması” başlıklı yüksek lisans tezinin bir bölümünden oluşturulmuştur.

**Arş. Gör., Pamukkale Üniversitesi Eğitim Fakültesi, Denizli-TÜRKIYE, e-posta: aytug.deu@gmail.com

***Prof.Dr., Dokuz Eylül Üniversitesi Buca Eğitim Fakültesi, İzmir-TÜRKIYY, e-posta: esra.bukova@ gmail.com
} 


\section{Giriş}

Mesleki gelişim programlarının temel amacı, öğretmenlerin matematiğe, öğrencilerinin matematiksel düşünmelerine ve öğretimsel stratejilere ilişkin bilgilerini ve anlayışlarını derinleştirmelerine yardımcı olmak ve öğretimi daha iyi hale getirebilmek için sınıf normlarını ve uygulamalarını geliştirmektir (Borko, 2004). Mesleki gelişim modellerinden biri olan ders imecesi, öğretmenlerin derslerin planlanmasını, uygulanmasını, gözlemlenmesini ve tartışılmasını içeren uygulamaları işbirliği içerisinde ve sistematik olarak gerçekleştirdikleri etkili bir mesleki gelişim modelidir (Lesson Study Research Group, 2013). Stigler ve Hiebert (2016) ders imecesinin öncelikli ve en önemli amacının mükemmel dersler ortaya koymak olmadığını vurgulayarak ders imecesini öğretmenlerin sonraki öğretimlerini geliştirmeleri için öğrenmelerini sağlayan bir araştırma süreci olarak tanımlamışlardır. Ders imecesi ile öğretmenler eğitim amaçlarına, öğretim programına, öğretim materyallerine, öğretim süreçlerine, öğrenci düşüncelerine ve öğrenmelerine ilişkin anlayışlarını geliştirmektedirler (Verhoef, Tall, Coenders ve Smaalen, 2013). Benzer şekilde, Murata (2011) ders imecesine katılan öğretmenlerin içerik ve öğrenci düşüncelerine ilişkin derin bir anlayış geliştirdiklerini ve öğretimlerini daha etkili hale getirebildiklerini vurgulamıştır. Ders imecesi boyunca gerçekleştirilen tüm uygulamaların ve etkinliklerin merkezinde öğrenciler yer almaktadır (Takahashi ve Yoshida, 2004). Dolayısıyla bu süreç sadece öğretmenlerin mesleki gelişimlerini değil öğrenci anlamalarının ve düşünmelerinin gelişimini de desteklemektedir. Ders imecesi grubunda öğretmenlerle birlikte en az bir uzman kişinin de yer alması gerekmektedir (Baki, 2012; Bütün, 2012; Fernandez, 2002; Lewis, 2002; Lewis, Perry ve Hurd, 2004; Walker, 2011). Fernandez, Yoshida, Chokshi ve Cannon (2001) uzmanların ders imecesi süresince farklı bir bakış açısı sağlama, matematiksel içerik, yeni fikirler ve reformlarla ilgili bilgiler sağlama ve ders imecesi grubundakilerle bu bilgileri paylaşma olmak üzere üç temel amacı olduğunu ifade etmektedirler. Paralel olarak, Takahashi (2014) uzmanların en önemli sorumluluklarından birinin öğretmenlerin ders kitaplarının ötesinde içeriğe, öğretim programına ve pedagojik fikirlere ilişkin derin bir anlayışa ulaşmalarını sağlamak olduğunu dile getirmiştir. Öğretmenlerin planlamayı birlikte yapmaları ve yanlarında uzman bir kişinin desteğini hissetmeleri kendilerine güven vermekte ve bu sayede gelişimlerini de desteklemektedir (Baki, 2012). Dolayısıyla etkili bir ders imecesi sürecinde uzmanların önemli bir yere sahip olduğu söylenebilir.

Bu çalışma kapsamında, ders imecesi modelinden yararlanırken beş aşamalı döngüsel süreç benimsenmiştir (bkz. Şekil 1). Süreç basamakları oluşturulurken Yoshida (1999), Lewis, Perry ve Murata (2006) ve Stigler ve Hiebert (1999) tarafindan ifade edilen ders imecesi döngüleri ve basamaklarından yararlanılmış ve araştırmacılar tarafından bu basamaklar bütünleştirilip açıklanmıştır.

Döngülerden de görülebileceği gibi, ders imecesinin ilk aşamasında öğretmenler kavrama ya da konuya ilişsin ayrıntılı incelemeler ve araştırmalar yapmaktadırlar. Bu incelemelerde öğretmenler kavramla ilgili ön bilgilerin neler olduğunu, kavramın tarihsel gelişim sürecini, öğrencilerin olası hatalarını ve kavram yanılgılarını ve konuyla ilgili öğretim programında hangi kazanımların yer aldığını ele almaktadırlar. Öğretmenlerin bu araştırmaları yaparlarken ders imecesinde yer alan uzmanların desteğini ve düşüncelerini dikkate almaları onlara hem kolaylık sağlamakta hem de kendilerini geliştirmek için firsat sunmaktadır. Araştırmalarını tamamlayan öğretmenler bir araya gelerek belirledikleri amaçlar doğrultusunda dersin planını hazırlamaktadırlar. Ders planı tamamlandıktan sonra gruptan bir öğretmen tarafindan gerçekleştirilen araştırma dersini diğer öğretmenlerin ve uzmanların gözlemlemeleri ders planının etkililiğini ve işlevselliğini uygulandığı süreçte değerlendirme imkânı sağlamaktadır. Planlamada karar verilen uygulamaların ders esnasında etkili olup olmadığını ders imecesi grubundaki herkesin gözlemlemesi ders planı uygulaması üzerinde zengin tartışmalar yapılmasını desteklemektedir. Dersin uygulamasının ardından yansıtma ve geliştirme toplantısında öğretmenler ve uzmanlar ders planını öğretim süresince ortaya çıkan durumları göz önüne alarak değerlendirmektedirler. $\mathrm{Bu}$ aşamada yaptıkları değerlendirmeler ile öğretmenler ders sırasında sıkıntı yaşanan durumları tekrar ele alma ve geliştirme firsatı bulmaktadırlar. Revize edilmiş 
planın uygulanmasından sonra ise ders gözlemleri doğrultusunda tekrar plan üzerinde tartışmalar yapılarak konuya ilişkin dersin nihai planına ulaşılmaktadır.

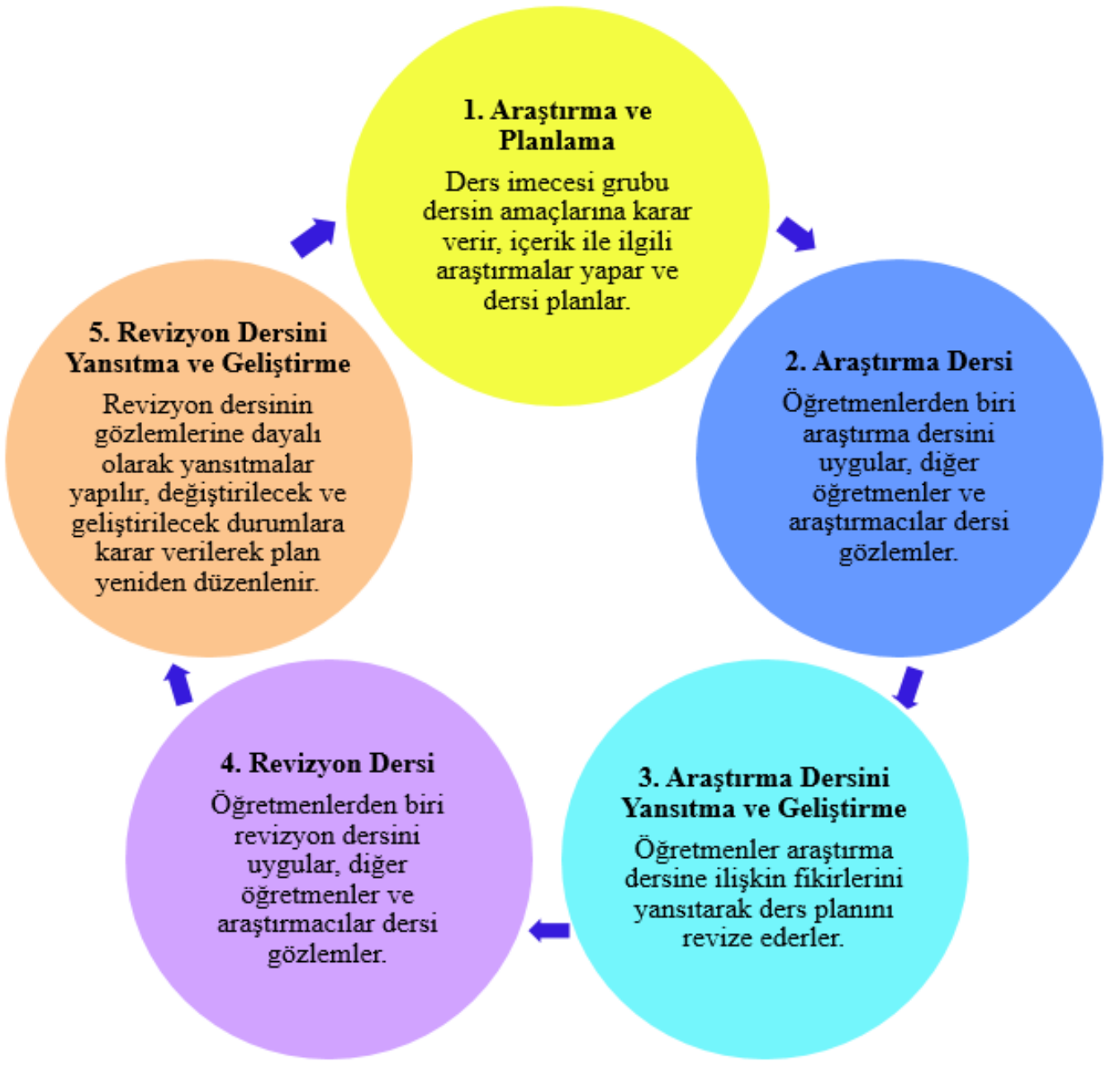

Şekil 1. Çalışmada yararlanılan ders imecesi döngüsü

Ders imecesinde dersler planlanırken öğrencilerin düşünceleri ve öğrenme süreçleri odağa alınmakta ve bu planlar doğrultusunda öğretimler gerçekleştirilmektedir. Bu bağlamda, döngüsel bir süreç olan ders imecesinin temel unsurlarından biri ders planı olarak karşımıza çıkmaktadır. İşbirliği içerisinde çalışılan bu süreçte, farklı bilgilere ve alışkanlıklara sahip öğretmenlerin fikirlerini ve araştırmalarını tartışmaları ve değerlendirmeleri ile hazırladıkları planlar derslerin etkililiğini arttırmaktadır. Hazırlanan ders planlarının kapsamlı olması ögretim sürecindeki olası sıkıntıların önüne geçebilmekte ve öğrenci öğrenmelerinin uygun şekilde yönlendirilmesinde yardımcı olabilmektedir. Ders imecesi boyunca hazırlanan planlar derslerde ve derslerin sonrasında yapılan yansıtma ve geliştirme toplantılarında değerlendirilmektedir. Böylelikle, öğretmenler herhangi bir planın uygulama süresince ortaya çıkan tüm durumları dikkate alarak hem gerekli gördükleri değişiklikleri revizyon dersinin planına yansıtmaktadırlar hem de bakış açılarını genişletme firsatı bularak ders planlama yaklaşımlarını zenginleştirebilmektedirler. Bu doğrultuda, ders imecesi gerçek sınıf ortamlarındaki derslerin farklı öğretmenlerin bakış açılarından değerlendirilmesini içerdiği için, uygun ders planlarının geliştirilmesi bağlamında oldukça etkilidir. 


\section{Ders Planı}

Ders planı, en temel haliyle, bir dersin akışının nasıl şekilleneceğini belirleyen bir rehberdir. Ders planı, öğretmenler için ders öncesinde ve ders esnasında gerçekleştirilecek etkinlikler için hatırlatıcı bir araç olup genellikle dersin ürünlerini, mantıksal bir şekilde sıralanan öğrenme etkinliklerini, değerlendirme etkinliklerini ve kriterlerini içermektedir (McCutcheon, 1980). Swearingen (2014) dersi planlamanın öğretim programının amaçları, öğrencilerin bireysel gereksinimleri, gerçek yaşam etkinlikleri veya ilgili etkinliklerle öğrencilerin katılımının sağlanması gibi hususların göz önüne alınarak ders boyunca gerçekleşecek eylemler ve yanıtlar için bir plan hazırlamak anlamına geldiğini ifade etmektedir. Uygun hazırlanan bir ders planı öğretmene öğretiminde oldukça yardımc1 olacağı ve öğrencilerin öğrenmelerini kolaylaştıracağı için hazırlanacak ders planında öğretmenin konuyu en verimli nasıl öğretebileceğini ve en uygun ders planını nasıl hazırlayabileceğini göz önüne alması gerekmektedir (Baki, Erkan ve Demir, 2012). Gerçekleştirilecek dersin amaçları ve içeriği dikkate alınarak planlama yapıldığ 1 için hazırlanan ders planının kapsamı amaca göre değișiklik gösterebilmektedir. Örneğin, öğrencilerin ilk kez karşılaşacakları bir matematik kavramını öğrenmeleri farklı hususlara dikkat etmeyi gerektirirken öğrenmiş oldukları bir kavrama yönelik çeşitli uygulamalar yapmaları farklı bir odağ gerektirmektedir. Şüphesiz öğretmenlerin dersleri planlarken dikkat etmeleri gereken belli başlı kriterler de vardır. Dersin amacı, hangi ön öğrenmeleri gerektirdiği, öğretim programının gereklilikleri ve derse nasıl başlanıp nasıl devam edileceği bunlardan bazılarıdır. Benzer olarak, Jones (2005) matematik derslerinin planlanmasında; (a) öğrencilerin matematiği nasıl öğrendiği, (b) matematik dersi öğretim programının yapısı, (c) öğretilecek konu, kavram ve becerilerin dikkate alınması, (d) öğrencilerin ön öğrenmelerine ilişkin bilgi, (e) matematiği öğretme yolları ve (f) derslerin en etkili hale gelmesi için nasıl planlanması gerektiği gibi konular üzerine düşünmek gerektiğini ifade etmektedir. Ball, Sleep, Boerst ve Bass (2009) planlama esnasında öğrencilerin ne gibi hatalar yapabileceklerinin, hangi kavram yanılgilarına sahip olabileceklerinin, nerelerde zorluk yaşayabileceklerinin ve nasıl akıl yürütebileceklerinin ve kavramların farklı gösterimlerinin neler olabileceğinin dikkate alınması gerektiğini vurgulamaktadırlar. Bunlara ek olarak, dersler planlanırken hem gerçekleştirilecek etkinliklere hem de bu etkinlikler için ne kadar süre ayrılacağına dikkat etmek planın içeriği ve işleyişi açısından faydalı olacaktır.

Bir matematik dersinin akışı, içerisinde pek çok etkinliği barındırabilir. Ontario Eğitim Bakanlığı raporlarında (2006) matematik dersinin akışı ve gerçekleştirilecek etkinlikler;

- dersin bölümlerini "başlangıç/giriş (getting started)", "geliştirme (working on it)" ve "yansitma ve ilişkilendirme (reflecting and connnecting)" olarak üç aşamada tasarlama,

- öğrencilerin akıl yürütmelerini desteklemek ve düşünmelerini sağlamak için bir soru veya problem ortaya atarak derse başlama,

- yeni matematiksel fikirleri mevcut kavramlarla ilişkilendirmeyi sağlayacak etkinlikler kullanma,

- öğrencilerin ilgili matematiksel kavrama odaklanmaları için sorular yöneltme,

- öğrencileri çoklu gösterimleri kullanmaya teşvik etme,

- öğrencilerin matematiksel düşüncelerini, stratejilerini ve çözümlerini paylaşma yollarını düşünme,

- öğrencilerin hangi araçları nasıl kullanacaklarına karar verme,

- dersin sonunda öğrencilerin yansıtmalarını veya öğrendikleri matematiksel bilgileri tartışmalarını sağlayacak süre ayırma olarak ifade edilmektedir.

Derslerin planlanması esnasında sıralanan bileşenlerin her birinin ele alınması uygun ders planlarının hazırlanmasında ve yürütülmesinde önemlidir. Bunların yanı sıra, ders sırasında beklenmeyen durumlarla karşılaşmak dersin akışını değiştirebilmektedir. Rowland, Turner, Thwaites ve Huckstep (2009) beklenmeyen durumlardan birini, öğretmenlerin derslerde öğrencilerin düşüncelerini dikkate almaları ve onlara yanıt vermeleri ile ortaya çıkabilecek durumlar olarak açıklamaktadırlar. Öğrenciler düşüncelerini ifade ettiklerinde öğretmen onların hatalarını, zorluklarını ve kavram yanılgılarını ortaya çıkarabilmektedir. Öğretim esnasında 
ortaya çıkan bu gibi durumlar öğretmen için bir firsattır ve plandan sapmayı da beraberinde getirmektedir. O halde ders planını durağanlıktan çıkarıp dinamik bir yapı olarak ele almak uygun olacaktır. Titizlikle planlanmış bir ders planı bile öğretim esnasında yeniden şekillenebilmektedir. Schoenfeld (2005) de gerektiğinde plandan ayrılarak dersin amaçları doğrultusunda öğretmenlerin derslerini yeniden düzenlemelerinin gerekliliğine vurgu yapmaktadır. Ders sırasında öğrencilerin düşüncelerinin ve öğretme sürecinin plandan sapmayı gerektirdiği durumlarda ögrretmenin bilgisi ve deneyimi ön plana çıkmaktadır. Borko ve Livingston (1989) deneyimli öğretmenlerle yaptıkları görüşmelerde öğretmenlerin yazılı olmadan zihinsel olarak ders planlarını ayrıntılı bir şekilde oluşturabildiklerini ve konuya nasıl giriş yapacakları veya kavramı nasıl açılayacakları konularını dikkatlice gözden geçirdiklerini ifade etmektedirler. Bununla birlikte deneyimli öğretmenlerin ders esnasında gerçekleştirilen etkinliklerde öğrencilerin yanıtlarına dayalı olarak çeşitli örnekler seçebildiklerini, gösterim şekillerinden yararlanabildiklerini, problemler belirleyebildiklerini, kavramsal açıklamalar yapabildiklerini ve uygun etkinliklerle öğrenmeyi gerçekleştirdiklerini belirtmişlerdir. Bir başka deyişle, deneyim arttıkça ders planlarının daha işlevsel ve uygun hale geldiği söylenebilir. Ders planlamasına yönelik öğretmen adayları ile gerçekleştirilen (Lloyd ve Behm, 2005; Baki ve Arslan, 2015) çalışmaların yanı sıra deneyimli öğretmenlerle öğretmen adaylarının ders planlarını karşılaştırmaya yönelik yapılan çalışmalar da (Borko ve Livingston, 1989; Kagan ve Tippins, 1992) bulunmaktadır. Mutton, Hagger ve Burn (2011) öğretmenlerin ders planı hazırlama becerilerinin nasıl geliştiğini inceledikleri çalışmalarında öğretmen adayları ile çalışmaya başlamışlar ve öğretmen adayları mezun olduktan sonra öğretmenliklerinin ilk iki yılında da onların ders planlarını incelemişlerdir. Öğretmen adaylarının öğrencilerin öğrenmelerine ve sınıfta ortaya çıkabilecek beklenmeyen durumlara ilişkin deneyimlerinin olmaması nedeniyle planlamada sıkıntılarının olduğunu belirtmişlerdir. Bu bağlamda mesleğinin çıraklık dönemini atlatmış deneyimli öğretmenlerle çalışmak, geliştirdikleri ders planlarını incelemek ve planların etkisini tartışmak önemlidir. Böylece hem öğretmenler hem de öğretmen adayları için konuya farklı açılardan bakmayı sağlayan modeller sağlanmış olacaktır. Ayrıca bir öğretmenin ders planlama sürecine odaklanmak yerine farklı ögretmenlerin deneyimlerini yansıttıkları planlama sürecini incelemek alanyazına katkı sağlayacaktır. Bu çalışma deneyimli üç matematik öğretmeninin uzmanlar rehberliğinde ders planları hazırlamaları ve bu planları uygulamalarının ardından yeniden düzenlemeleri sebebiyle bu katkıyı destekleyecektir.

Standart bir ders planı formatında, öğretmenlerin amacı, dersin aşamaları, gerçekleştirilecek etkinlikler, öğretmen ve öğrenci eylemleri gibi faktörler ele alınmaktadır. Bu tarz bir planda, ögretmenlerin deneyimlerine ve öğretime bakış açılarına göre vurguladıkları hususlar değişiklik gösterebilmektedir. Çalışma kapsamında öğretmenlere standart bir ders planı formatı sağlanmasının yanı sıra Smith, Bill ve Hughes (2008) tarafindan ortaya koyulan ders planı protokolü Türkçeleştirilerek (bkz. Ek A) verilmiştir. Standart bir ders planının aşamaları öğretmenlere sadece derste yapılacaklarla ilgili yol gösterirken Smith, Bill ve Hughes'un (2008) ders planı kılavuzu, öğretmenleri öğrencilerinin matematiksel anlamalarını desteklemek ve ne düşündüklerini dikkate almak için öğretecekleri dersleri derinlemesine düşünmeye teşvik eden bir içeriğe sahiptir. Gerçekleştirilecek ders imecesinde amaç öğretmenlerin öğrenci düşüncesi bilgilerinin gelişimini sağlamak olduğu için bu süreçte öğretmenlerin öğretimleri esnasında öğrenci düşüncelerini ön planda tutmalarını sağlayacak bir ders planlama kılavuzunun gerekliliği sebebiyle bu kılavuz ders planı formatına entegre edilerek öğretmenlere sunulmuştur. Bu kılavuz öğretmenlerin tüm süreç boyunca öğrencilerine ve öğrencilerinin düşüncelerine odaklanmalarını sağlamaktadır. Kılavuzda yer alan sorular öğretmenlerin yapacakları araştırmalar için yol gösterici olmaktadır. Araştırmalarını tamamlayan öğretmenler ders planı kılavuzu yardımıyla giriş, geçiş-geliştirme ve kapanış olarak üç aşama halinde sınıf içi etkinlikleri öğrenci düşünceleri bağlamında ele alarak ayrıntılı bir plan oluşturmaktadırlar.

Kılavuzun birinci aşaması, "Amaçları Belirleme-Etkinliği Seçme ve Düzenleme” olup bu aşamada, öğretmenler derste uygulayacakları etkinlikleri seçerlerken/tasarlarlarken/ hazırlarlarken bunları hangi öğretimsel amaçlarla ilişkilendireceklerini belirlemelidirler. Öğretmenlerin dersin hangi kavramları içerdiğini ve bu kavramların konunun diğer kısımları ile 
ilişkilerini göz önüne almaları önem taşımaktadır. Belirlenen etkinliklerin öğrencilerin hangi ön bilgileri ile ilişkilendirileceği, hangi materyallerin ve gösterimlerin kullanılacağı gibi uygulama esnasında belirleyici olan etkenlerin önceden değerlendirilmesi gerekmektedir. $\mathrm{Bu}$ değerlendirmelerde öğrencilerin etkinlik üzerinde çalışmaları sonucunda hangi kazanımlara ulaşacakları da belirlenmelidir. Böylece öğretmenler ders sırasında daha bilinçli ve verimli bir öğretim gerçekleştirebileceklerdir.

Ders planı kılavuzunun "Etkinlik Süresince Öğrenciyi Destekleme" olarak adlandırılan ikinci aşamasında, öğrenciler bir etkinlik üzerinde çalışırlarken onlara sorulacak soruların belirlenmesi ön plana çıkmaktadır. Öğrencilerin düşüncelerinin hangi sorularla ortaya çıarılabileceğinin ve geliştirilebileceğinin önceden planlanması ile etkinlik öğrencileri öğrenmeye götürmede daha etkili olacaktır. Buna ek olarak, öğrencilerin olası yanıtlarının ve çözüm yaklaşımlarının onlara etkili dönütler verebilmek için önceden düşünülmesi gerekmektedir. Öğrencilerin hangi sorulara ne şekilde yanıt verecekleri, dersin hangi aşamasında zorluk yaşayabilecekleri, ne gibi hatalar yapabilecekleri göz önüne alınarak ders planının hazırlanması ders esnasında ortaya çıkabilecek sıkıntıların da önüne geçecektir. Öğretmenin karşılaşacağı her türlü duruma hazırlıklı olmasını sağlayan bir planla dersini gerçekleştirmesi beklenmeyen durumlarla başa çıkabilmesine destek olacaktır.

Kılavuzun son aşaması olarak, öğrencilerin etkinliğe yönelik çözümlerinin paylaşılması ve tartışılması aşaması yer almaktadır. Öğretmenler plan yaparlarken öğrencilerin olası çözümlerini ve fikirlerini tartışı bunlarla ilgili değerlendirmelerini de göz önüne almalıdırlar. Ögrencilerin farklı fikirlerini desteklemek ve birbirleriyle etkileşim kurmalarına yardımcı olmak için önceden belirlenmiş farklı öğrenci yaklaşımlarından yararlanılmaktadır. Öğretmenlerin tüm bu faktörleri dikkate almasını sağlayan bu ders planı kılavuzu dersin giriş, geçiş-geliştirme ve kapanış olmak üzere her aşamasında öğrencilerin düşüncelerinin geliştirilmesine ve kavramsal öğrenmelerinin desteklenmesine imkân vermektedir. Öğrenci düşüncelerinin sürekli incelendiği ve tartışıldığı bu süreç ders planının öğrencilerin öğrenmesinde önemli bir araç haline gelmesini de sağlamaktadır.

$\mathrm{Bu}$ çalışmada, ders imecesi grubunun 9.sınıf düzeyinde "Köklü ifadeleri açıklar, özelliklerini belirtir ve uygulamalar yapar." ve "Bir gerçek sayının rasyonel sayı kuvvetini örneklerle açıklar, köklü ifadelere ait işlemlerin özelliklerini üslü ifadelerin özelliklerinden yararlanarak gösterir ve uygulamalar yapar.” (MEB, 2013a; s. 6) kazanımlarına yönelik gerçekleştirmeye karar verdikleri ilk döngüye ait derslerin planları ele alınmıştır. Bilindiği gibi, lise matematik derslerinde farklı dereceye sahip köklü ifadelere, bunlara yönelik işlemlere, cebirsel ifadeleri içeren köklü ifade uygulamalarına yer verilirken, öğrenciler köklü ifadelere ilişkin ilk deneyimlerini ortaokul 8.sınıf düzeyinde "kareköklü ifadeler" (MEB, 2013b, s. 35) alt öğrenme alanının öğretimi ile kazanmaktadırlar. Bu süreçte de, kareköklü ifadeler ile irrasyonel sayılara geçiş yapılmaktadır.

\section{Köklü Ífadeler}

Güven, Çekmez ve Karataş (2011) ülkemizde irrasyonel sayılara geçisin 8. sınıf düzeyinde kareköklü sayılar ile başladığına ve Pisagor teoreminden yararlanarak elde edilen kareköklü sayıların reel sayı doğrusunda geometrik gösteriminin yapıldığına dikkat çekmektedirler. 8. sınıf düzeyinde düşünüldüğünde kareköklü sayılar ile hem rasyonel sayılardan farklı sayıların olduğu ortaya koyulmakta hem de bu sayıların sayı doğrusunda yerinin belirlenmesi ve böylece kareköklü sayıların sıralanmasına da geçiş yapılması hedeflenmektedir. Öğrenciler için farklı ve soyut bir kavram olan kareköklü sayılar güçlükleri de beraberinde getirmektedir. İşleyen ve Mercan (2013), 8. sınıf öğrencilerinin kareköklü sayılara ilişkin güçlüklerini incelemişler ve güçlükleri öğrencilerin kareköklü sayıları sayı doğrusunda gösterme ve sıralama, karesel bölgenin alanı ile kareköklü sayılar arasında ilişki kuramama ve kareköklü sayılarda yanlış gerçekleştirilen işlemler olarak ifade etmişlerdir. Özkan (2011) da köklü ifadeleri dokuzuncu sınıf düzeyindeki öğrencilerin güçlük yaşadığı kavramlardan biri olarak belirtmiş ve güçlükleri kareköklü sayıların günlük yaşamda açıkça kullanılmamasına ve öğrencilerin doğal sayılar, tamsayılar ve rasyonel sayılarla ilgili her kuralı köklü ifadelere genellemeye çalışmalarına bağlamaktadır. Zazkis ve 
Sirotic (2006) irrasyonel sayılara ilişkin çalışmaların çok az sayıda olduğunu belirtirlerken irrasyonel sayıların öğrenciler tarafından soyut bir kavram olarak görüldüğünü ve öğrencilerin irrasyonel sayıların geometrik gösterimlerini bilmediklerini ifade etmektedirler. Özellikle 8. sınıf düzeyinde ilk kez ele alınan irrasyonel sayı kavramının kareköklü sayılar ile bütünleştirilerek açıklanması nedeniyle geometrik gösterim öğrencilerin kavramsal anlaması için gerekli olacaktır. Fischbein, Jehiam ve Cohen (1995) de öğrencilerin reel sayıları anlamalarını sağlamak için sadece rasyonel sayıları değil aynı zamanda irrasyonel sayıları da tanımlamak gerektiğini ve bu sayede reel sayı sisteminin tutarlı ve bütüncül olarak ortaya çıkarılacağını vurgulamaktadırlar. Erlandson (2013), köklü ifadelerin anlatımını incelediği dört ders kitabında köklü ifadelerin ya doğrudan tanımından hareketle açıklandığına ya da köklü ifadeler ile üslü ifadeleri ilişkilendirerek açıklandığına ancak geometrik yorumunun yapılmadığına dikkat çekmiştir. Lise düzeyi için düşünüldüğünde geometrik gösterim öğrencilerin bildiği bir bilgidir. Bu bağlamda ön bilgileri hatırlatmak anlamında geometrik yorum ele alınabilir ancak lise ve üniversite düzeyi için öğrencilerin denklemin kökleri ile köklü ifadeleri ilişkilendirmeleri gerekmektedir. Roach, Gibson ve Weber (2004), $(A) \sqrt{25}=5$ ve $(B) \sqrt{25}= \pm 5$ şeklinde iki ifadenin doğruluğunun üniversite birinci sınıf öğrencilerine sorulması durumunda çoğu öğrencinin ikinci ifadenin doğru

olacağı yanıtını vereceklerini ifade etmektedirler. Devamında $\sqrt{25}^{\prime}$ in tek bir pozitif reel sayıya karşılık geldiğini onun da 5 olduğuna dikkat çekerlerken öğrencilerin bu konudaki yanılgılarının nedenini ise cebir kitaplarında sıklıkla yapılan

$$
\begin{array}{r}
x^{2}=25 \\
x= \pm 5
\end{array}
$$

gösterimine bağlamaktadırlar. Kitaplarda yer alan yukarıdaki gösterim yerine aşağıdaki geçişlerin ele alınmasıyla tam anlamıyla doğru bir gösterim yapılacağını ve öğrencilerin kareköklü ifadelerde güçlük yaşamasının önüne geçileceğini vurgulamaktadırlar.

$$
\begin{aligned}
x^{2} & =25 \\
\sqrt{x^{2}} & =\sqrt{25} \\
|x| & =\sqrt{25} \\
x & = \pm 5
\end{aligned}
$$

Yaptıkları bu gösterimde $|x|=\sqrt{25}$ denkleminin çözümünden dolayı $x= \pm 5$ sonucunun ortaya çıktığını vurgulamak istemektedirler. Gómez ve Buhlea (2009) köklü ifadelerin tarihsel gelişim içerisinde karenin kenar uzunluğu veya kübün bir ayrıtına işaret ederek ele alınması nedeniyle negatif olmadığı için ikinci dereceden bir denklemin pozitif kökü ile ilişkilendirilmesine ihtiyaç duyulmadığını ancak günümüzde bir sayının karekökünün tek bir değer olacağının vurgulanması gerektiğini belirtmektedirler. Ayrıca öğrencilerin mutlak değer kullanmayı gerektiren köklü ifadelerde sıkıntılar yaşadıklarına dikkat çekmektedir. Crison (2012) da öğrencilere $\sqrt{16}$ 'nın değeri sorulduğunda öğrencilerin \pm 4 yanıtını verirlerken $\sqrt{32}$ 'nin değeri sorulduğunda $4 \sqrt{2}$ yanıtını verdiklerine ve bu hatanın ikinci dereceden bir denklemin köklerinin bulunma sürecinden kaynaklandığına dikkat çekmektedir. Grosser-Clarkson (2015) bir sayının karesi 9 ise bu sayının " 3 mü?" yoksa " -3 mü?" olduğunun kesin bilinemeyeceğini ve ancak $\sqrt{9}=3$ olacak şekilde tek sonucun olduğunu belirtmekte ve bunu $\sqrt{9}$ ile karesi 9 olan sayıları bulmanın birbirinin tersi olmadığı ile açıklamaktadır. Bunu doğrudan $f(x)=x^{2}$ fonksiyonun ters fonksiyonunu bulma ile ilişkilendirebiliriz. Fonksiyonun birebir ve örten olduğu aralıkta tersini almak mümkün olacağından bu fonksiyonun tersini

$$
\begin{gathered}
f^{-1}:[0,+\infty) \rightarrow[0,+\infty) \\
f^{-1}(x)=\sqrt{x}
\end{gathered}
$$

şeklinde ifade ederiz ki bu bize karekökün neden denklemin pozitif kökü ile ilişkili olduğunu gösterir.

Ulusal ve uluslararası alanyazın açısından ele alındığında köklü ifadelerin öğretimine ilişkin çalışmaların gösterim, öğrenci güçlükleri, pozitif-negatif kök ve kareköklü sayıların ilişkilendirilmesine dayalı olduğu görülmektedir. Kitaplarda sunulan benzer yaklaşımların yanı 
sıra köklü ifadelere geçişte öğretmenlerin nasıl bir öğretim gerçekleştirmeleri gerektiği ve dersleri nasıl planlamaları gerektiği önem kazanmaktadır.

$\mathrm{Bu}$ çalışmada üç matematik öğretmeninin öğrenci düşüncesi bilgilerinin gelişimine yönelik dokuz aylık üç döngüyü içeren ders imecesinin ilk döngüsünde hazırlanan köklü ifadelere odaklanılmıştır. Çalışmanın amacı, ders imecesi döngülerine katılan üç matematik öğretmeninin 9.sınıf düzeyinde köklü ifadelerin giriş kısmının öğretimine yönelik hazırladıkları ve revize ettikleri ders planlarını incelemektir. Ders planları değerlendirilirken ders planı kılavuzundaki üç bölüm için incelemeler gerçekleştirilmiş ve revizyon edilen bölümler ve revizyonun nedenleri ayrıntılı açıklanmaya çalışılmıştır. Bu bağlamda çalışmada yanıt aranan araştırma soruları şu şekildedir:

1.Ders planının giriş aşaması ders imecesi süresince nasıl yapılandırılmaktadır?

2.Ders planının geçiş ve geliştirme aşaması ders imecesi süresince nasıl yapilandirılmaktadır?

3.Ders planının kapanış aşaması ders imecesi süresince nasıl yapılandırılmaktadır?

\section{Yöntem}

Üç matematik öğretmenin gerçekleştirdiği ders imecesinin ilk döngüsü kapsamında köklü ifadelere ilişkin geliştirilen ders planının incelenmesi amacıyla gerçekleştirilen bu çalışma nitel durum çalışması desenine dayanmaktadır. Çalışmada, öğretmenlerin hazırladıkları ders planları ve bu ders planlarını uyguladıkları araştırma ve revizyon dersleri ayrıntılı olarak incelendiği için durum çalışması deseni uygun görülmüştür. Ders imecesi boyunca öğretmenlerin birlikte çalışarak araştırma dersi için ortaya koydukları ders planı araştırmada derinlemesine incelenen bir durum iken, bu planın üzerinde değişiklikler ve düzenlemeler yaparak oluşturdukları revizyon dersi planı ise diğer durumdur.

\section{Çalışma Grubu}

Bu araştırmada amaçlı örnekleme yöntemlerinden tipik durum örnekleme yöntemi ile bir devlet lisesinde görev yapmakta olan on üç yıllık deneyime sahip üç matematik öğretmeni katılımcı olarak seçilmiştir. Patton'a (1987) göre tipik durum örneklemesinde amaç, ortalama durumları çalışarak belirli bir alan hakkında fikir sahibi olmak veya söz konusu alan, konu, uygulama veya yenilik konusunda yeterli bilgi sahibi olmayanları bilgilendirmektir (aktaran Yıldırım ve Şimşek, 2011). Katılımcı öğretmenler bakış açıları açısından Türkiye için ortalama öğretmen profiline uymaları ve tipik deneyimli öğretmen özelliklerini taşımaları sebebiyle bu öğretmenlerle gerçekleştirilen uygulama ve ortaya çıkarılan sonuçların farklı okullardaki matematik öğretmenleri için yol gösterici olabileceği düşünülmüştür. Öğretmenlerin çalıştıkları okulun, araştırmacıların çalıştığı üniversiteye yakın olması da ders imecesi kapsamında gerekli olan etkileşimler için kolaylık sağlamıştır. Ancak, bu durum öğretmenlerin katılımcı olarak seçilmelerinde bir kriter olmamakla birlikte süreç içerisinde esneklik sağlaması açısından etkisini gösteren bir faktör olmuştur.

Öğretmenlerle bu çalışmayı gerçekleştirebilmek için etik kurul izin başvurusunda bulunulmuş ve İl Milli Eğitim Müdürlügünden gerekli izinler alınmıştır. Çalışmaya gönüllü olarak katılan öğretmenler üniversitede öğrenim görürlerken tanışmışlar ancak birlikte çalıştıkları süre içerisinde birbirleriyle bir konunun öğretimi üzerine herhangi bir paylaşımda bulunmamışlardır. Okulda matematik sınavları tüm sınıflarda ortak gerçekleştirildiği için, dersler kapsamında tek paylaştıkları nokta, bir sonraki sınava kadar öğretimi yapılacak konular hakkında olmuştur.

Çalışmanın bulguları sunulurken katılımcı öğretmenlerin gerçek isimleri gizli tutularak belirlenen takma isimlerle ilgili bilgiler sunulmuştur. Üç öğretmen de matematik öğretmenliği bölümünde lisanslarını tamamlamışlar ancak Ali lisans programı sonrasında matematik bölümünden yüksek lisans derecesini de almıştır. Öğretmenlere ilişkin bilgiler Tablo 1'de verilmiştir. 
Tablo 1

Katılımc1 Öğretmenlere İlişkin Bilgiler

\begin{tabular}{cccc}
\hline Kişi & Cinsiyet & Öğrenim Durumu & Deneyim yılı \\
\hline Ali & Erkek & Yüksek Lisans Mezunu & 13 \\
Özden & Bayan & Lisans Mezunu & 13 \\
Serin & Bayan & Lisans Mezunu & 13 \\
\hline
\end{tabular}

Katılımcılarla ders imecesi öncesinde öğrenci düşüncesi bilgisine ve ders imecesinin önemli bir aşaması olan planlamaya ilişkin fikirlerini ortaya çıkarmak amacıyla yarı yapılandırılmış görüşmeler yapılmıştır. Bu görüşmeler ile Ali'nin dersleri için bir plan yapmadığı, deneyimlerine dayanarak derslerini gerçekleştirdiği ve öğrencilerine soracağı sorularını da ders esnasında belirlediği ortaya çıkmıştır. Ders planı olmadığı için ders sırasında ele almadığı durumları ögrencilerinin kendisine bu duruma ilişkin soru sorduklarında fark ettiğini ifade etmiştir. Özden de dersine yönelik formal bir plan yapmamakta ancak öğretimini gerçekleştireceği konuya ilişkin içeriğin sırasını, çözeceği soruları ve bu soruların çözümlerini yazdığı ajandası yardımıyla dersini gerçekleştirmektedir. Benzer şekilde, Serin ayrıntılı bir ders planı hazırlamak yerine ders öncesi vereceği içeriğin sırasını not alarak ve çözeceği soruları yararlandığı kitaplardan belirleyerek derse hazırlık yapmaktadır.

\section{Veri Toplama}

Çalışmanın verileri ders imecesinin ilk döngüsü kapsamındaki öğretmenlerin planlama ve revizyon aşamalarındaki grup görüşmeleri, iki saati araştırma dersi ve iki saati revizyon dersi olmak üzere dört saatlik ders gözlemleri, bu derslere ilişkin transkriptler ve ders planları ve öğretmenlerin yansıtıcı günlükleri oluşturmaktadır.

Ders imecesi grubunu oluşturan öğretmenlerle ilk olarak ders planı kılavuzu (bkz. Ek A) paylaşılarak kılavuzda yer alan sorular tartışılmıştır. Bu süreçte öğretmenlere bir dersi planlarken öğrenci düşüncelerine nasıl odaklanacaklarına ilişkin farkındalık kazandırılmaya çalışılmıştır. Tartışmalar kapsamında herhangi bir kavram seçilmeksizin matematik dersinin planlanması üzerine genel konuşulmuş ancak köklü ifadelerin öğretiminin nasıl gerçekleştirileceğine yönelik yönlendirmeler yapılmamıştır. Ardından öğretmenler ilk döngüyü hangi konu ve sınıf düzeyinde gerçekleştireceklerini düşünmüşler ve ders imecesi sürecini göz önünde bulundurarak 9. ve 10. sınıf düzeyinde uygulamalar yapmaya karar vermişlerdir. Bu sınıf düzeylerinde ise öğretim programının akışına uygun ve önceki deneyimleri doğrultusunda öğrencilerin güçlük yaşadıkları konuları ele almayı amaçlamışlardır.

İlk araştırma dersini 9.sınıf düzeyinde "köklü ifadeler" konusunda gerçekleştirmeye karar veren öğretmenler planlamaya geçmeden önce konuyla ilgili ön çalışmalar gerçekleştirmişlerdir. Ayrıca bu süreçte araştırmacılar uzmanlar olarak öğretmenlere destek olabilmek amacıyla köklü ifadelere ilişkin kavram yanılgılarını, öğrenci zorluklarını ve köklü ifadelerin tarihsel gelişimini içeren matematik eğitimi alanına özgü makaleler ve kitaplar sunmuşlardır. Ek olarak, köklü ifadelerin öğretiminde kullanabilecekleri kavram karikatürlerini ve konunun tarihsel gelişimine ve önemine değinen videoları içeren öğretim materyalleri sağlamışlardır. Araştırmacılar Türkçe olmayan kaynakları Türkçeleştirerek öğretmenler için kullanılabilir hale getirmişlerdir. Öğretmenler yaptıkları araştırmalar, inceledikleri çalışmalar ve belirledikleri amaçlar doğrultusunda işbirliği ile araştırma dersinin planını hazırlamışlardır. Konunun içeriği, kullanılacak kaynaklar, sorulacak sorular gibi tüm ders içeriğine kendileri karar veren öğretmenlere araştırmacılar doğrudan müdahalelerde bulunmamışlardır. Öğretim materyallerini kullanıp kullanmama, kullanılmasına karar verilen materyallerden dersin hangi aşamasında yararlanılacağını belirleme ve materyallerle amaçları ilişkilendirme hususlarına da öğretmenler kendileri karar vermişlerdir. Ancak araştırmacılar toplantılarda öğretmenlere öğrenci düşüncelerini dikkate almalarını sağlayacak sorular sormuşlar ve onları alışkanlıklarının ötesine geçmeleri için teşvik etmişlerdir. Bir başka deyişle, araştırmacıların müdahaleleri öğretmenlere ne yapacaklarını söylemek yerine onların kavram ve öğretimi üzerine düşünmelerini ve kafa 
karışıklığı yaşadıkları konuların üstüne yoğunlaşmalarını sağlamak amacıyla gerçekleştirilmiştir. İki araştırmacı da planlama aşamasında öğretmenleri gözlemlemiş, alan notları almış ve verdikleri kararları daha iyi anlayabilmek için onlarla grupça görüşmüşlerdir. Bu şekilde, ders imecesinin birinci aşaması olan araştırma ve planlama, ders imecesi grubu tarafindan tamamlanmıştır. $\mathrm{Bu}$ süreçte herhangi bir veri kaybı olmaması için tartışmalar video kamera ile kaydedilmiştir. Planlamanın ardından Ali planı hazırlanan dersin öğretimini gerçekleştirirken, diğer öğretmenlerle birlikte araştırmacılar da araştırma dersini gözlemlemişlerdir ve ders boyunca alan notları almışlardır. Toplantılara benzer şekilde, gerçekleştirilen dersler de veri kaybını önlemek için biri tahtayı diğeri öğrencileri görecek şekilde iki video kamera ile kaydedilmiştir. Ardından, öğretmenler ve araştırmacılar uygulanan araştırma dersini yansıtmak amacıyla tekrar bir araya gelmişler ve öğrenci düşünceleri bağlamında dersin olumlu ve olumsuz yanlarını tartışmışlardır. Araştırmacılar bu toplantının öncesinde dersin videosunu izleyerek notlar almışlar ve kendi aralarında tartışarak kritik noktaları belirlemişlerdir. Öğretmenlerin de dersin videolarını toplantıdan önce izlemelerini istemişlerdir. Öğretmenlerin araştırma dersine ilişkin kendi belirledikleri noktaları değerlendirmelerini yanı sıra araştırmacılar da kendi gözlemledikleri durumlarla ilgili dersin belirli kesitlerine öğretmenlerin dikkatlerini çekmişlerdir. $\mathrm{Bu}$ süreçte öğretmenler belirledikleri amaçları göz önüne alarak söz konusu ders planını revize etmişlerdir. Revizyon dersini Özden yürütürken, Ali ve Serin ile birlikte araştırmacılar da dersi gözlemlemişlerdir. Araştırma dersinde olduğu gibi revizyon dersinden sonra da bir araya gelinerek ders ve plan hakkında tartışmalar gerçekleştirilmiştir. Bu aşamada da araştırmacılar öncesinde ders videolarını izleyerek ve araştırma dersi ile karşılaştırarak önemli kesitleri belirlemişlerdir. Toplantı esnasında belirledikleri kesitleri de öğretmenlerin düşünmelerini sağlamışlardır. Öğretmenler planda yapılmasını gerekli gördükleri revizyonlara karar vererek köklü ifadelere ilişkin son planı ortaya koymuşlardır. Döngü sonunda öğretmenlerin "Ders imecesinin planlama aşamasında köklü ifadeler ilgili hangi hususlar göz önünde bulunduruldu?, Birlikte ders planı yapmamış olsaydınız dersin hangi kısımlarında farklılıklar olurdu?, "Araştırma dersinde hazırlanan planın uygulanmasında ne gibi aksaklıklar oldu?", "Revizyon dersinde ilk dersten farklı olarak nelere yer verildi, bunun sebepleri nelerdir?" gibi sorulara yanıt vererek yansıtıcı günlükler yazmaları istenmiştir.

\section{Verilerin Analizi}

Verilerin analizinde, araştırmacılar analiz birimi olan araştırma dersinin ve revizyon dersinin planlarını, giriş, geçiş-geliştirme ve kapanış aşamaları doğrultusunda toplantılarda gerçekleştirilen tartışmaları ve alan notlarını dikkate alarak betimsel analiz ile incelemişlerdir. Ders planının giriş, geçiş-geliştirme ve kapanış aşamaları öğretmen eylemleri ve ders planı kılavuzundaki sorular göz önüne alınarak analiz edilmiştir. $\mathrm{Bu}$ süreçte, öğretime uygun yaklaşımlara, ortaya çıkan öğrenci güçlüklerine ve nedenlerine, gerçekleştirilen ilişkilendirmelere ve öğretmenlerin plan ve öğretimlerine yönelik karar verdikleri değişikliklere ve nedenlerine odaklanılmıştır. Planlarda değişiklik yapılan kısımlar ve değişikliklerin nedenleri ortaya koyulurken derslerden ve toplantılardan kesitler verilmiştir. Ek olarak, araştırma dersinin ve revizyon dersinin planı sürekli olarak karşılaştırılmış ve karşılaştırma yaparken ders planı kılavuzunda yer alan sorular araştırmacılara yönlendirici olmuştur. Özellikle araştırma dersinin planından farklı olarak yapılanlar nedenleriyle birlikte yorumlanmıştır. Analizleri iki araştırmacı birlikte gerçekleştirmişler ve süreç boyunca düşüncelerini birbirleriyle paylaşarak inceledikleri verilere ilişkin fikir birliğine ulaşmışlardır. Analiz sürecinde oluşturulan ders planları ayrıntılı olarak incelenirken aynı zamanda öğretmenlerin gelişimleri de dikkate alınmıştır.

\section{Bulgular}

Araştırma soruları doğrultusunda yapılandırılan bulgular sunulurken, öğretmenlerin hazırladıkları planlar giriş, geçiş-geliştirme ve kapanış aşamaları açısından ele alınmış ve her aşama ders imecesinin basamakları bağlamında ayrıntılandırılmıştır. Planlama, uygulama ve revizyon aşamaları boyunca yapılanları ve değişiklikleri nedenleriyle ortaya koymak için toplantılardaki tartışmaları, derslerdeki öğrenci-öğretmen etkileşimlerini ve yansıtıcı günlüklerdeki öğretmen 
ifadelerini içeren kesitlere yer verilmiştir. Derslerin ve görüşmelerin ilgili kesitlerinde bağlam dışı bölümler ya da konuşmalar analiz sonucunda ortaya çıkan bulguların odak noktasını etkilemeyecek şekilde çıkarılmış ve bu kısımlar için “ooo" gösterimi kullanılmıştır.

\section{Ders Planının Giriş Aşamasına Yönelik Bulgular}

Araştırma Dersi Giriş̧ Aşamasının Planlama Toplantısı

Öğretmenler ders imecesinin ilk döngüsünü köklü ifadeler üzerine gerçekleştirmeye karar verdikten sonra köklü ifadelere yönelik bir takım araştırmalar yapmışlardır. Konunun gerekli ön bilgilerinin ve daha önceki sınıf düzeylerinde köklü ifadelerin ön gerekliliği olarak öğrencilere öğretilen içeriğin ne olduğunu belirlemek amaciyla ortaokul ve lise matematik dersi öğretim programlarını incelemişlerdir. İlk planlama toplantısında öğretmenler araştırmacılar tarafindan onlara sunulan ve kendi araştırmaları ile ulaştıkları köklü ifadelere yönelik çeşitli videoları izlemişlerdir. Ek olarak, derslerinde hangi öğretim araçlarını kullanabileceklerini belirlemeye çalışmışlardır. Bu aşamada, negatif kök ve pozitif kök ifadelerini içeren bir kavram karikatürünü (bkz. Şekil 2) inceleyerek negatif kök ve pozitif kök kavramlarının öğrenciye nasıl sunulabileceğini tartışmışlardır. Aşağıda verilen kesitten de görülebileceği gibi Ali kareköklerin negatif olabilmesinin mümkün olmadığını ifade etmiş ve öğrencilere verilmemesi gerektiğini vurgulamıştır. Bunun üzerine Özden ders kitabını inceleyerek kitapta pozitif karekök ve negatif karekök ifadelerinin yer aldığını göstermiş ve bu durumu kavramların hatalı olmadığına bir kanıt olarak düşündüğünü ifadelerine yansıtmıştır. Ancak Ali, Özden'in kitapta ilgili bölümü göstererek belirttiği ifadelerin doğru olmadığına değinmiş ve doğru olmadığını düşündügü bir ifadeyi sadece kitapta yer aldığı için derste ele almayacağını açıklamıştır. Ali bu süreçte pozitif ve negatif kökün varlığına ikinci dereceden denklemlerin çözümlerinden hareketle yer vermiştir. Ancak pozitif karekök ifadesinin doğru olmadığı yönündeki ısrarına devam etmiştir. Bu nedenle söz konusu durum araştırma dersinin planına dahil edilmemiştir.

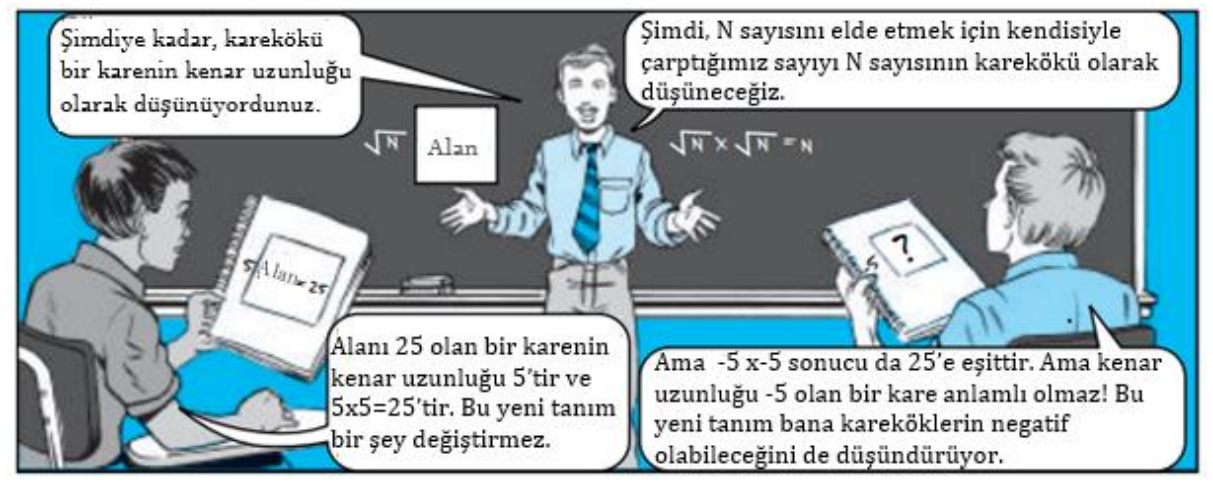

Şekil 2. Kareköke ilişkin Kavram Karikatürü (Education Development Center, 2005)

\begin{tabular}{|c|c|}
\hline Ali: & $\begin{array}{l}\text { Kareköklerin negatif olabileceği ne demek ki? Mesela } 64 \text { 'ün karekökleri } \\
\text { nelerdir?[karikatürü anlamaya çallşlyor] }\end{array}$ \\
\hline Özden: & 64 'ün karekökleri +8 ve -8 . \\
\hline Ali: & 64'ün karekökü 8'dir ama. \\
\hline Serin: & $\begin{array}{l}\text { Böyle bir șey de var ama biz 8'i kullanıyoruz mu diyeceğiz o zaman? Nasll } \\
\text { söyleyeceğiz, onu öyle bağlamamız lazım. }\end{array}$ \\
\hline Özden: & Bir dakika, karekökleri dediğin zaman ikisini de söylemiyor musun? \\
\hline Ali: & Hayır, karekök bir tanedir. \\
\hline Özden: & $\begin{array}{l}\text { Ama bak burada derecesi tek olduğu zaman bir tane, çift olduğu zaman iki } \\
\text { tane. [karikatürü gösteriyor] }\end{array}$ \\
\hline Serin: & $\begin{array}{l}\text { Ama kural olarak bir tane oluyor ya. } \\
\qquad \text { Ooo }\end{array}$ \\
\hline zden: & $\begin{array}{l}\text { Bir şey söyleyebilir miyim ama bakın kitaptaki yazımı da } \\
\text { kitabından okuyor.] 36'nın karekökleri } 6 \text { ve }-6 \text { 'dır. Bur } \\
\text { pozitif karekök denir. }\end{array}$ \\
\hline
\end{tabular}




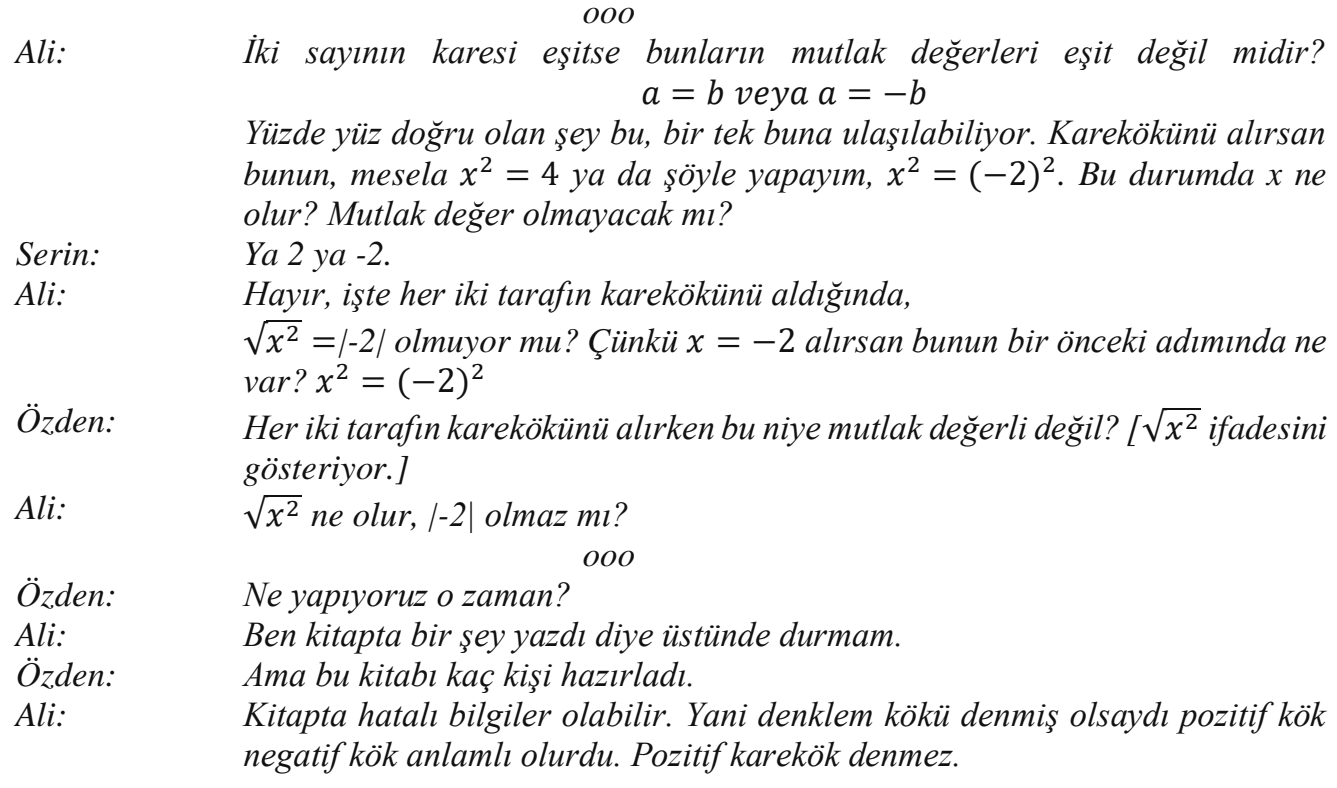

$\mathrm{Bu}$ toplantıda daha çok dersin giriş kısmına odaklanan öğretmenler dersin amacının ne olduğu, ders kapsamında nelere yer verecekleri ve ne tür araçları kullanabilecekleri gibi ders planı kılavuzunun ilk kısmında yer alan bazı soruları yanıtlamışlardır. Alan bilgisi üzerine yapılan tartışmaların yoğunluklu olduğu bu toplantıda araștırmacıların sorularıyla öğrencilerin ne düşünebilecekleri ya da hangi ön bilgilere sahip oldukları üzerine fikir belirtmişlerdir. Aşağıdaki kesitte görülebileceği gibi, araştırmacı, öğretmenlerin öğrenci bilgilerini ortaya çıkarmaya ve öğretmenlerin planı hazırlarken öğrencileri dikkate almalarının gerekliliğini fark ettirmeye çalışmışır.

\begin{tabular}{|c|c|}
\hline Araştırmacl: & Öğrencilerin ön bilgileri nelerdir? \\
\hline Özden: & $\begin{array}{l}\text { Kökün dışına sadeleştirme işlemini yapabiliyorlar yani a } \sqrt{b} \text { haline } \\
\text { getiriyorlar kökün içindeki sayıları. Küçükten büyüğe sıralayabiliyorlar } \\
\text { kareköklü sayıları. Sonra çarpanlarına ayırabiliyorlar kökün içindeki sayıyı. }\end{array}$ \\
\hline Ali: & $\begin{array}{l}\text { Topluyorlar karekökleri, çıkartıyorlar, çarpma yapabiliyorlar, bölme de } \\
\text { yapabiliyorlar. Üslü biçimde yazmayı bilmiyorlar galiba. }\end{array}$ \\
\hline Özden: & $\begin{array}{l}\text { Üslü biçimde yazmayı bilmiyorlar aynen öyle. ... İki tane kareköklü sayıyı } \\
\text { toplamayı çıkarmayı çarpmayı bölmeyi biliyorlar ama derecesi iki } \\
\text { olmayanların işlemlerini bilmiyorlar. }\end{array}$ \\
\hline Araştırmacl: & $\begin{array}{l}\text { O halde ögrenciler kareköklü ifadelerle işlem yapmayı biliyorlar ancak henüz } \\
\text { farklı kök derecelerini bilmiyorlar bir de köklü ifadeler ile üslü ifadeler } \\
\text { arasındaki ilişkiyi yeni görecekler. }\end{array}$ \\
\hline Ali: & nu da almamı gerekiyor. \\
\hline
\end{tabular}

Birbiriyle etkili tartışmalar gerçekleştiremeyen öğretmenler içeriği belirleme konusunda ortak bir karara varamamışlar, dolayısıyla planı tamamlayamamışlardır. Bunun nedeni öğretmenlerin birbirleriyle kavramlar hakkında yeni yeni tartışmaya başlamış olmaları, bazı kavramlarda kafa karışıklıkları yaşamaları ve düşündükleri ile ve kitapta yer alan ifadeler arasında uygun ilişkilendirmeleri yapamamalarıdır. Bu süreçte hem fikir olamayan öğretmenler daha fazla araştırma yapmaya ve planı tamamlamak için ikinci kez toplanmaya karar vermişlerdir.

Ders planı kılavuzdaki sorulara yanıt aramaya çalıştıkları ikinci toplantıda öğretmenler, ders planını oluştururken ağırlıklı olarak ders kitabındaki konu sıralamasına bağlı kalmaya karar vermişlerdir. Araştırma dersine yönelik öğretmenlerin hazırladıkları planının giriş aşaması (bkz. Tablo 2) incelendiğinde, öğretmenler köklü ifadelerin yapılandırılmasında temel ön bilgi olduğu ve kılavuzun ilk aşamasında ön bilgilerle ilişkilendirmeye vurgu yapıldığı için öğrencilere kareköklü ifadeler ile ilgili sorular sorarak başlamanın uygun olacağını düşünmüşlerdir. $\mathrm{Bu}$ 
soruları sorarak daha yüksek dereceden köklü ifadelerin öğretiminden önce öğrencilerin zihinsel olarak hazır hale geleceklerini dikkate almışlardır. Ek olarak, bu sorularla öğrencilerin karekök kavramına ilişkin ön bilgilerini hatırlamalarını destekleyeceklerini ve öğrencilerin karekök ve üslü ifadelere ilişkin bilgilerinden yararlanarak köklü ifadelerin anlamını hissedeceklerini düşünmüşlerdir. Ayrıca küpü verilen bir sayıyı belirleme şeklindeki sorularla da bir sayının küp köküne geçiş yapılacağını tartışarak "Küpü 8 olan sayı kaçtır?" şeklinde soruları da giriş aşamasına eklemişlerdir. Öğretmenlerin toplantı sırasında ders planının giriş kısmına karar verirken gerçekleştirdikleri konuşmalardan alınan bir kesit şu şekildedir:

$\begin{array}{ll}\text { Araştırmacı: } & \text { Derse nasıl başlamayı düşünüyorsunuz? } \\ \text { Özden: } & \text { Soruyla başlayalım. } \\ \text { Serin: } & \text { Evet, soruyla. } \\ \text { Ali: } & \text { Karesi } 36 \text { olan sayı nedir gibi bir soruyla olabilir. Orada } 36 \text { değil de } 16 \text { da } \\ & \text { diyebiliriz. Aynı şey. } \\ \text { Özden: } & \text { Sonra üçüncü kök, dördüncü kök, beşinci kök hepsine tek tek bakıyoruz. } \\ \text { Ali: } & \text { Aslına bakarsanız zaten karekökle ilgili her şeyi biliyorlar. Bizim burada } \\ & \text { üzerinde duracağımız kısım daha üst dereceden olanlar. } \\ \text { Özden: } & \text { Zaten köklü ifadelere diyerek başlamış, karekök değil. } \\ \text { Ali: } & \text { Mesela sonra kimin küpü 8'dir gibi sorular sorabiliriz. }\end{array}$

Tablo 2

Araştırma Dersi Planının Giriş Aşaması

\begin{tabular}{|c|c|c|c|c|}
\hline & Etkinlik ve Süresi & $\begin{array}{c}\text { Etkinliğin Seçilme } \\
\text { Nedeni }\end{array}$ & $\begin{array}{c}\text { Öğretmen } \\
\text { Eylemi/Rolü }\end{array}$ & $\begin{array}{c}\text { Öğrenci } \\
\text { Eylemi/Rolü }\end{array}$ \\
\hline & $\begin{array}{l}\text { Soru sorma }(10 ') \\
\text { 1.Köklü ifade ne } \\
\text { demektir? } \\
\text { 2.Kök içindeki sayı } \\
\text { hangi pozitif sayının } \\
\text { karesidir? } \\
\text { 3.Karesi } 4 \text { olan sayılar } \\
\text { nelerdir? } \\
\text { 4.Küpü } 8 \text { olan sayı } \\
\text { kaçtır? } \\
\text { 3. } \sqrt{4}, \sqrt{16}, \sqrt{-4} \text { vb. } \\
\text { kaçtır? }\end{array}$ & $\begin{array}{l}\text { Öğrencilerin ortaokulda } \\
\text { görmüş oldukları } \\
\text { kareköklü ifadelere } \\
\text { ilişkin ön bilgilerini } \\
\text { ortaya çıkarmak, varsa } \\
\text { hatalı bilgilerini } \\
\text { gidermek ve eksik } \\
\text { bilgilerini tamamlamak, } \\
\text { ilgili } \\
\text { kavram/konu/gösterimleri } \\
\text { hatırlamalarını sağlamak } \\
\text { ve yeni konuya } \\
\text { 1sındırmaya çalışmak/ön } \\
\text { hazırlık yapmak }\end{array}$ & $\begin{array}{l}\text { Öğrencilere } \\
\text { belirlenen } \\
\text { soruları sorar, } \\
\text { öğrencilerin } \\
\text { düşüncelerini } \\
\text { ortaya } \\
\text { çıararmaya } \\
\text { çalışır, } \\
\text { gerektiğinde ek } \\
\text { sorularla } \\
\text { düşüncelerini } \\
\text { genişletir, } \\
\text { hatalı/eksik } \\
\text { bilgilerini } \\
\text { gidermeye/ } \\
\text { geliştirmeye } \\
\text { çalışır. }\end{array}$ & $\begin{array}{l}\text { Soruları } \\
\text { yanıtlar, } \\
\text { birbirlerinin } \\
\text { düşüncelerini } \\
\text { dinler ve } \\
\text { fikirlerini } \\
\text { açıklar. }\end{array}$ \\
\hline
\end{tabular}

Araştırma Dersi Planı Giriş Aşamasının Öğretimde Uygulanması

Öğretmenlerin planlama toplantısında karar verdikleri gibi Ali üslü ifadelere ve kareköklü ifadelere ilişkin sorular sormuş ve öğrencilerinin ortaokulda öğrenmiş oldukları ön bilgilerini hatırlamalarını sağlamıştır. Öğrenciler kareköklü ifadelerin ne olduğu sorusu üzerine karekök ifadesi ile ilgili bilgilerini hatırlamaya çalışmışlar ve sayının kendisiyle çarpımı ya da sayının karesi ile ilişkilendirme yapmışlardır. Planın giriş aşamasının öğretimde uygulandığı bölümden alınan kesit aşağıda verilmiştir:

\footnotetext{
Ali: [Tahtaya köklü ifadeler yazdı.] Evet, köklü ifadelere başlayalım. Köklü ifadelerle ilgili kim ne biliyor?

Ögrenci 1: $\quad$ Bir tane sayı oluyor köklü ifade. Onun içinden kendisiyle çarpımı çıkıyor dışarı.
} 


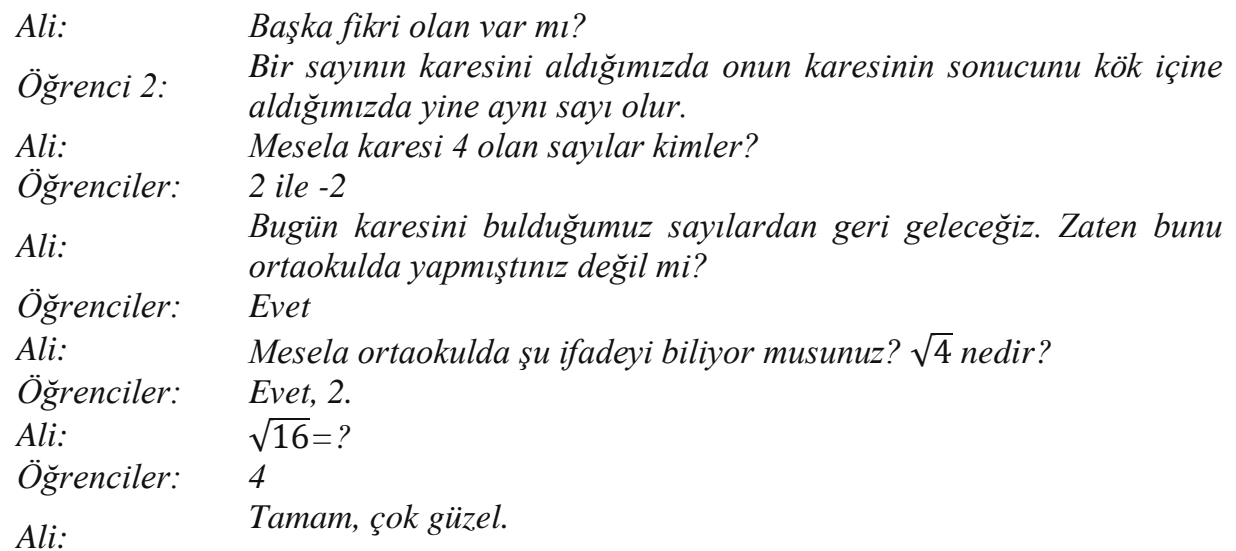

Öğretmenler planlamada karekök simgesinin içinde negatif sayıların olması halinde tanımsız bir sayı elde edileceğini ve öğrencilerin bildikleri sayılardan farklı bir sayı olduğunu söylemenin öğrenciler için yeterli olacağına karar vermişlerdi. Planlama toplantısında karar verdikleri gibi Ali, araştırma dersinde $\sqrt{-4}$ sayısının değerinin ne olacağını öğrencilere sormuş ve fazla açıklama yapmadan bu sayının onlar için tanımsız olduğunu belirtmiştir. Aşağıdaki kesitte Ali'nin bu sorusuna ilişkin öğrenci yanıtları ve Ali'nin açıklamaları verilmiştir.

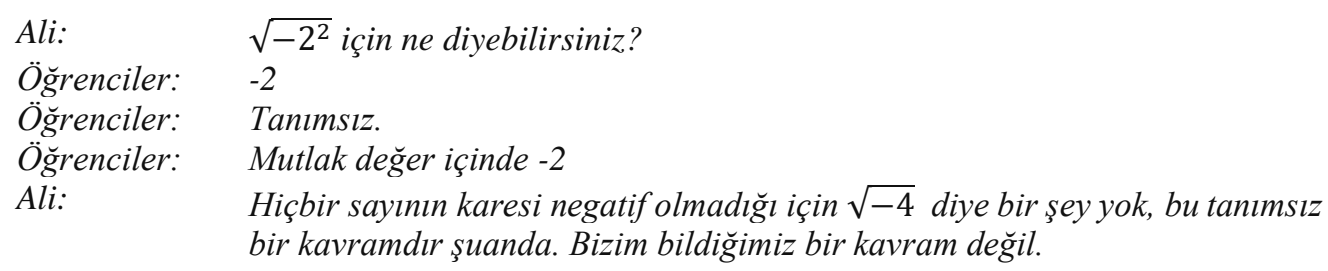

Araştırma Dersi Planının Giriş Aşamasına ilişkin Yansitma ve Geliştirme Toplantısı

Araştırma dersinin ardından yapılan yansıtma ve geliştirme toplantısında öğretmenler gözlemleri doğrultusunda derse giriş aşamasında herhangi bir sıkıntı olmadığını ve Ali'nin köklü ifadelere geçiş yapmadan önce öğrencilerinin ön bilgilerini etkili bir şekilde kullanmalarını sağladığını ifade etmişlerdir. Dolayısıyla dersin bu bölümünün içeriği için herhangi bir düzeltme ya da değişiklik yapmamışlardır.

Ali'nin dersinde $\sqrt{-4}$ sayısının değerinin ne olacağına ilişkin açıklamaları yansıtma ve geliştirme toplantısında ele alınan durumlardan biri olmuştur. Öğretmenler karekök simgesinin içinde negatif bir sayı olması halinde sayının reel sayı olmadığını öğrencilere matematik dilini kullanarak ifade etmenin gerekli olacağını toplantıda belirtmişlerdir. 11.sınıfların matematik derslerine giren Serin karekök içerisindeki negatif sayıların karmaşık sayılarla ilişkilendirilip açıklama yapılabileceğini ifade etmiştir. Ders kitabındaki $\sqrt{-36}$ ifadesini gören öğretmenler böyle bir sayının öğrencilere verilip verilmeyeceğine yönelik tartışmalarını derinleştirmişlerdir. Sonrasında Serin yenilenen öğretim programına tam hakim olmadığı için karmaşık sayıların programın içeriğinden kaldırıldı ğını ifade ederek $\sqrt{-36}$ gibi sayıları öğrencilerin bilmemelerinin eksiklik olmayacağını söylemiştir. Öğretmenlerin bu konuya ilişkin konuşmalarından alınan kesit aşă̆ıdaki gibidir:

$\begin{array}{ll}\text { Özden: } & \text { Karesi }-36 \text { olan sayılar [ders kitabındaki örneği okuyor.] } \\ \text { Serin: } & \text { Aslında karmaşı sayılarla ilgili onlara değinilebilir, eksi sayıların } \\ & \text { kareköklerini şimdi değil de daha sonra göreceksiniz şeklinde. Hatta onlar } \\ & \text { göremeyecek bile. Yeni programda karmaşık sayl yok. } \\ \text { Özden: } & \text { Onereden çıkıordu. İkinci dereceden denklemde } \Delta \text { 'sı 0'dan küçük olanlarda. }\end{array}$


Serin: $\quad$ Yani burada da söylenebilir. Hani biz normalde 0 ya da 0’dan büyük olan sayıların kareköklerini alabiliriz. Aslında eksi olan sayıların da karekökü var diye. Aslında genişletilmiş oluyor reel sayılar. Ama şimdi karmaşık sayıları kaldırdılar, bilmeseler de olabilir.

Ali: $\quad$ Karmaşık say yok mu artık?

Serin: $\quad$ Yeni sistemde yok, sifir.

$\mathrm{Bu}$ noktada araştırmacılar toplantı esnasında karmaşık sayıların yenilenen öğretim programından tamamen çıkarılmadığına ve temel kavramların öğretiminin yer aldığına dikkat çekmişler ve bunun üzerine konuşmuşlardır. Böylelikle, öğretmenler öğrencilere söylenen " $\sqrt{-4}$ diye bir şey yok" ifadesinin onların ileriki sınıf düzeylerinde karşılaşacakları karmaşık sayı kavramına zıt bir durum oluşturabileceği sonucuna varmışlardır. Zihinlerinde oluşabilecek olası bir kavram karmaşasının önüne geçmek için bu noktada planı revize etmeye ve $\sqrt{-4}$ biçimindeki bir sayının reel sayı olmadığına ilişkin cebirsel gösterimi yapmaya karar vermişlerdir.

Araştırma dersinin giriş kısmına yönelik yansıtma ve geliştirme toplantısında üzerinde durulan hususlardan bir diğeri negatif kök ve pozitif kök ayırımının verilmesinin gerekliliği olmuştur. Ali negatif karekök ifadesinin doğru olmadığını düşündüğünden ve zihninde bu durumu anlamlandıramadığından ve araştırma dersinin planlamasında bu hususa karar veremediklerinden araştırma dersinin planında bu gibi bir ayrıma yer vermemişlerdi. Ancak öğretmenler dersi gözlemledikten sonra "Karesi 4 olan sayılar nelerdir?" sorusuna öğrencilerin verdikleri 2 ve -2 yanıtlarının negatif/pozitif köklü ifadeleri ile açıklanmasının önemli olduğunu belirtmişler ve ders kitabında ifade edildiği gibi "negatif karekök" şeklinde adlandırmalara yer vermeden revizyon dersi planına ekleme yapmaya karar vermişlerdir.

\section{Revizyon Dersi Planı Giriş Aşamasının Öğretimde Uygulanması}

Revizyon dersinde Özden öğrencilerin karekök içerisinde negatif bir sayının reel sayılarda bir karşılığı olmadığını daha açık bir şekilde anlamalarını sağlamak için bu tür sayıların gerçek sayı olmadığı ve $\mathbb{R}$ kümesinin elemanı olmadığı ifadelerine yer vermiş ve cebirsel gösterimi yapmıştır. Özden'in dersinden alınan kesit aşağıdaki gibidir:

$$
\begin{array}{ll}
\text { Özden: } & x^{2}=-64 \text { Yani x’in karesi -64 'e eşit olan sayılar nelerdir desem? Bana } \\
& \text { hangi gerçek sayıları söylersiniz? } \\
\text { Ögrenciler: } & \text { Boş küme. } \\
\text { Özden: } & \text { Reel sayılarda hiçbir sayının karesi -64'e eşit değil. } \\
& \sqrt{-64} \notin \mathbb{R} \\
& \text { O zaman ben ters işlem yapacak olursam karekökün içerisine -64 yazdığım } \\
& \text { zaman herhangi bir reel sayı bulma şansım yok. Buradan karekökün içerisinin } \\
& \text { de negatif olmayacağ gibi bir yorum yapabiliyorum. Bu gibi sayları } \\
& \text { 11.sınıfta öğreneceksiniz. }
\end{array}
$$

Araştırma dersinde yer verilmeyen negatif ve pozitif kök kavramlarının ayrımı toplantıda karar verildiği gibi revizyon dersi kapsamında ele alınmıştır. Ancak, "pozitif kök-negatif kök" olarak karar verilen terminolojiyi Özden dersinde ders kitabında verildiği şekli ile kullanarak "pozitif karekök-negatif karekök" gibi öğrencileri yanılgıya düşürecek doğru olmayan söylemlere yer vermiştir. Özden'in bu süreçteki yaklaşımı ve açıklamaları aşağıdaki kesitte verilmiştir.

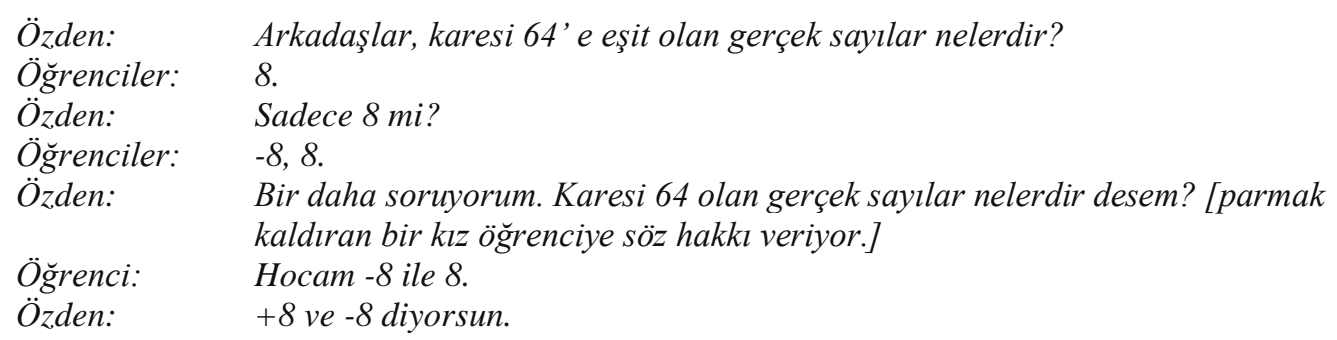


x'in, şimdi ben bu saylya söylediğim ifadeyi matematiksel hale getirecek olsam karesi 64 olan saylyı bulurken üslü ifadelerde öğrendiğim işlemleri yapacak olursam,

$x^{2}=64$

$x^{2}=8^{2}$

$x=8$ diyebilirim veya

$x^{2}=(-8)^{2}$

$x=-8$ dir, diyebilirim.

Bulmuş olduğum 8 ve -8 dediğim sayllar 64 'ün karekökleridir.

Biz arkadaşlar şimdi kare alma işlemini üslü ifadeyi kullanarak bu köklere ulaş̧tı, bunların içerisindeki 8'e pozitif karekök, -8'e de negatif karekök adını veriyoruz. Ama karekök sembolünü kullanırken sadece işaretsiz olan kısmı için kullaniyoruz.

Yani arkadaşlar kökleri yazarken $\sqrt{64}$ için 8 ifadesini kullanıyorum.

$\sqrt{64}=8$

Ama karesi 64 olan sayllar dediğim zaman +8 ve -8 'i düşünüyorum. İki tane kökü var ama biz karekök sembolünü sadece pozitif olan kökler için kullaniyoruz.

Revizyon dersinin yansıtma ve geliştirme toplantısında öğretmenler, giriş aşamasında denklemin kökleri, kümeler, üslü ifadeler, pozitif-negatif kök ayrımı ile karekök ilişkisi için revizyon dersinde yapılan anlatımının daha uygun olduğuna karar verdiler. Ancak Özden'in negatif kök ve pozitif kök yerine negatif karekök ve pozitif karekök ifadelerini kullanmasının yanlış olduğu ve öğrencilerde yanılgılar oluşturabileceği için düzeltilmesi gerektiği üzerine konuşmuşlar ve bu konuda hemfikir olmuşlardır.

\section{Ders Planının Geçiş-Geliştirme Aşamasına Yönelik Bulgular}

Araştırma Dersi Geçiş-Geliştirme Aşamasının Planlama Toplantısı

Öğretmenler kareköklü ifadelerden köklü ifadelere geçiş için öğrencilere $\sqrt[3]{27}$ ifadesinin ne anlama geldiğini sorarak, onları mevcut fikirlerini irdelemeye teşvik ederek kavramın genel tanımını sezmelerini amaçlamışlardır. Bunun ardından doğrudan matematiksel tanımı öğrencilere açıklamaya ve bu tanımı pekiştirmelerine yönelik sorular sormaya karar vermişlerdir. Araştırma dersinin planının Geçiş-Geliştirme aşamasının ilk kısmı Tablo 3’te sunulmuştur.

Tablo 3

Araştırma Dersi Planının Geçiş-Geliştirme Aşaması

\begin{tabular}{|c|c|c|c|c|}
\hline & Etkinlik ve Süresi & $\begin{array}{l}\text { Etkinliğin } \\
\text { Seçilme } \\
\text { Nedeni }\end{array}$ & $\begin{array}{c}\text { Öğretmen } \\
\text { Eylemi/Rolü }\end{array}$ & $\begin{array}{c}\text { Öğrenci } \\
\text { Eylemi/Rolü }\end{array}$ \\
\hline 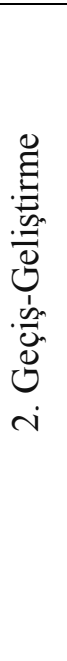 & 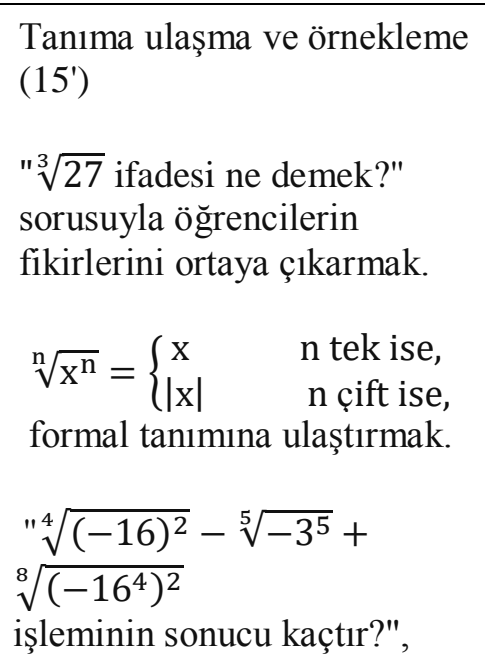 & $\begin{array}{l}\text { Tek ve çift } \\
\text { dereceli } \\
\text { kökleri farklı } \\
\text { sayısal } \\
\text { örnekleri } \\
\text { tartışarak } \\
\text { n.dereceden } \\
\text { köklü } \\
\text { ifadelerin } \\
\text { formal } \\
\text { tanımına } \\
\text { ulaştırmak, } \\
\text { köklü ifadelere } \\
\text { ilişkin }\end{array}$ & $\begin{array}{l}\text { Sorular sorarak } \\
\text { öğrencileri formal } \\
\text { tanıma ulaştırmak, } \\
\text { tek ve çift dereceli } \\
\text { köklü ifadelerin } \\
\text { nasıl yazılacağını } \\
\text { açıklamak ve } \\
\text { formal tanımı } \\
\text { yazar. } \\
\text { Öğrencilerin } \\
\text { tanımı } \\
\text { pekiştirmeleri için } \\
\text { sinıf tartışması } \\
\text { şeklinde sorular } \\
\text { sorar, yanıtı }\end{array}$ & $\begin{array}{l}\text { Soruları } \\
\text { yanıtlayarak } \\
\text { sınıf } \\
\text { tartışmasına } \\
\text { katılır, ön } \\
\text { bilgileri ile } \\
\text { ilişkilendirme } \\
\text { yaparak formal } \\
\text { tanımı } \\
\text { anlamlandırır. }\end{array}$ \\
\hline
\end{tabular}


$\sqrt{(\sqrt{5}-1)^{2}}-\sqrt{(2-\sqrt{5})^{2}}$

uygulamalar yapmak

işleminin sonucu kaçtır?

" $x, y$ ve z reel sayıları için,

$x<0<y<z$ ise

$\sqrt[4]{x^{4}}-\sqrt[3]{(-y)^{3}}+$

$\sqrt{z^{2}}$ toplamı kaçtır?"

sorularını sorarak öğrencilerin

tanımı pekiştirmelerini

sağlamak.

Köklü ifadelerin tanımının verilmesinden sonra öğretmenler üslü ifadelerle köklü ifadeleri ilişkilendirmeyi planlamışlardır (bkz. Tablo 4). İlişskilendirmeyi $\sqrt[3]{8}$ ifadesini $8^{\frac{1}{3}}$ şeklinde de yazılabileceği örneğini vererek ele almayı düşünmüşlerdir.

Tablo 4

Araştırma Dersi Planının Geçiş-Geliştirme Aşaması

\begin{tabular}{|c|c|c|c|c|}
\hline & $\begin{array}{l}\text { Etkinlik ve } \\
\text { Süresi }\end{array}$ & $\begin{array}{c}\text { Etkinliğin Seçilme } \\
\text { Nedeni }\end{array}$ & Öğretmen Eylemi/Rolü & $\begin{array}{c}\text { Öğrenci } \\
\text { Eylemi/Rolü }\end{array}$ \\
\hline 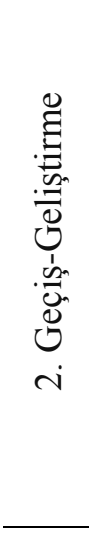 & $\begin{array}{l}\text { Üstü ifadelerle } \\
\text { ilişkilendirme ve } \\
\text { sıralama }\left(15^{\prime}\right) \\
\sqrt[n]{a^{m}=a^{\frac{m}{n}}} \\
\text { eşitliği belirtilir } \\
\text { ve örnek olarak } \\
\sqrt[3]{8^{\prime} \text { 'in } 8^{\frac{1}{3}}} \\
\text { şeklinde } \\
\text { yazllabileceği } \\
\text { söylenir. }\end{array}$ & $\begin{array}{l}\text { Köklü ifadelerle } \\
\text { üslü ifadeleri } \\
\text { ilişkilendirmek, } \\
\text { köklü ifadeleri } \\
\text { siralamak ve } \\
\text { bunları } \\
\text { pekiştirmek }\end{array}$ & $\begin{array}{l}\text { Öğrencilerin köklü } \\
\text { ifadelerle daha önce } \\
\text { öğrendikleri üslü } \\
\text { ifadeler arasındaki } \\
\text { ilişkiyi kurmalarını } \\
\text { sağlayan sorular sorar } \\
\text { ve sıralama yapmalarını } \\
\text { gerektiren sorular } \\
\text { sorarak köklü ifadelerin } \\
\text { sıralanmasını } \\
\text { pekiştirmelerini } \\
\text { destekler. }\end{array}$ & $\begin{array}{l}\text { Önceki bilgilerini } \\
\text { hatırlayarak } \\
\text { ilişkilendirmeyi } \\
\text { yapar ve } \\
\text { öğretmenin sorduğu } \\
\text { sorulara fikir üretir } \\
\text { ve düşüncelerini } \\
\text { açıklar. }\end{array}$ \\
\hline
\end{tabular}

Araştırma dersinin planında köklü ifadelerle çarpma ve bölme ve iç içe kök olan işlemlerinin (bkz. Tablo 5) yapılabileceği kararını vererek planı düzenlemişlerdir. Bu bağlamda hem kök dereceleri eşit köklü ifadelerin çarpımına yönelik sorular seçmişler hem de farklı kök derecelerine sahip köklü ifadelerin çarpımına ilişkin sorularla öğrencilerin akıl yürütmelerini istemeye karar vermişlerdir.

Tablo 5

Araştırma Dersi Planının Geçiş-Geliştirme Aşaması

\begin{tabular}{|c|c|c|c|c|}
\hline & Etkinlik ve Süresi & $\begin{array}{l}\text { Etkinliğin } \\
\text { Seçilme } \\
\text { Nedeni } \\
\end{array}$ & Öğretmen Eylemi/Rolü & $\begin{array}{c}\text { Öğrenci } \\
\text { Eylemi/Rolü }\end{array}$ \\
\hline i & $\begin{array}{l}\text { Çarpma İşlemi-Soru } \\
\text { sorma (15') }\end{array}$ & $\begin{array}{c}\text { Üslü } \\
\text { ifadelerden } \\
\text { yararlanarak } \\
\text { köklü }\end{array}$ & $\begin{array}{c}\text { Öğrencilerin üslü } \\
\text { ifadelerden yararlanarak } \\
\text { köklü ifadelerde çarpma } \\
\text { işleminin nasıl }\end{array}$ & $\begin{array}{c}\text { Üslü ifadelerden } \\
\text { yararlanarak } \\
\text { köklü ifadelerde } \\
\text { çarpma işleminin }\end{array}$ \\
\hline
\end{tabular}




\begin{tabular}{|c|c|c|c|}
\hline $\begin{array}{l}2 \sqrt{3} \cdot 5 \sqrt{2} \text { işleminin } \\
\text { sonucu kaçtır? } \\
\sqrt{3} \cdot \sqrt[4]{2} \text { işleminin } \\
\text { sonucu kaçtır? } \\
\sqrt{2} \cdot \sqrt[3]{2} \cdot \sqrt[4]{2} \text { işleminin } \\
\text { sonucu kaçtır? } \\
\sqrt[4]{2} \cdot \sqrt[6]{3} \cdot \sqrt[12]{7} \text { işleminin } \\
\text { sonucu kaçtır? }\end{array}$ & $\begin{array}{c}\text { ifadelerde } \\
\text { çarpma } \\
\text { işlemini } \\
\text { yapmak ve } \\
\text { farklı kök } \\
\text { derecelerinin } \\
\text { nasıl } \\
\text { çarpılacağına } \\
\text { yönelik akıl } \\
\text { yürütmek }\end{array}$ & $\begin{array}{c}\text { yapılacağını } \\
\text { keşfetmelerini sağlar ve } \\
\text { buna uygun sorular sorar, } \\
\text { öğrencilerin } \\
\text { yanıtlarını/düşüncelerini } \\
\text { sorgular. }\end{array}$ & $\begin{array}{c}\text { nasıl } \\
\text { yapılabileceğini } \\
\text { düşünür, ak1l } \\
\text { yürütür, soruları } \\
\text { yanıtlar ve } \\
\text { yaptıklarını } \\
\text { açıklar. }\end{array}$ \\
\hline $\begin{array}{l}\text { Bölme İşlemi- Soru } \\
\text { sorma }\left(10^{\prime}\right) \\
\\
\frac{\sqrt{20}}{\sqrt{5}} \text { işleminin sonucu } \\
\text { kaçtır? } \\
\frac{\sqrt[3]{4}}{\sqrt{2}} \text { işleminin } \text { sonucu } \\
\text { kaçtır? }\end{array}$ & $\begin{array}{c}\text { Üslü } \\
\text { ifadelerden } \\
\text { yararlanarak } \\
\text { köklü } \\
\text { ifadelerde } \\
\text { bölme işlemi } \\
\text { yapmak }\end{array}$ & $\begin{array}{c}\text { Öğrencilerin üslü } \\
\text { ifadelerden yararlanarak } \\
\text { köklü ifadelerde bölme } \\
\text { işleminin nasıl } \\
\text { yapılacağını } \\
\text { keşfetmelerini sağlar ve } \\
\text { buna uygun sorular sorar, } \\
\text { öğrencilerin } \\
\text { yanıtlamalarına imkan } \\
\text { verir. }\end{array}$ & $\begin{array}{c}\text { Üslü ifadelerden } \\
\text { yararlanarak } \\
\text { köklü ifadelerde } \\
\text { bölme işleminin } \\
\text { nasıl } \\
\text { yapılabileceğini } \\
\text { düşünür, soruları } \\
\text { yanıtlar ve } \\
\text { yaptıklarını } \\
\text { açıklar. } \\
\end{array}$ \\
\hline $\begin{array}{l}\text { x pozitif reel sayısı } \\
\text { için, } \frac{\sqrt{x \sqrt[3]{x}}}{\sqrt[3]{x \sqrt[4]{x}}} \text { sonucu } \\
\text { nedir? }\end{array}$ & $\begin{array}{l}\text { İç içe geçmiş } \\
\text { kökleri } \\
\text { kavramak ve } \\
\text { içerisinde iç } \\
\text { içe geçmiş } \\
\text { kökler olan } \\
\text { soruları } \\
\text { çözmek }\end{array}$ & $\begin{array}{c}\text { Öğrencilerin iç içe olan } \\
\text { köklü ifadeleri } \\
\text { kavramalarını sağlamak } \\
\text { için sorularıyla } \\
\text { yönlendirmeler yapar. } \\
\text { Bunları içeren örneklerle } \\
\text { farklı şekillerde çözüme } \\
\text { ulaşabileceklerini fark } \\
\text { ettirir. Sorular sormak ve } \\
\text { düşünmeleri için firsat } \\
\text { verir. }\end{array}$ & $\begin{array}{c}\text { Köklü ifadelerle } \\
\text { ilgili } \\
\text { kavradıklarını iç } \\
\text { içe olan köklü } \\
\text { ifadelerde nasıl } \\
\text { kullanacağını } \\
\text { düşünür ve } \\
\text { öğretmenin } \\
\text { sorularına fikir } \\
\text { yürütür. } \\
\text { Arkadaşlarının } \\
\text { açıklamalarını } \\
\text { dinler. }\end{array}$ \\
\hline
\end{tabular}

\section{Araştırma Dersi Planı Geçiş-Geliştirme Aşamasının Öğretimde Uygulanması}

Araştırma dersinin planı geçiş-geliştirme aşamasının uygulamasında Ali yazılı ders planını sürekli elinde tutmadığı için formal tanımın ardından öğrencilere $(\sqrt{5}-1)^{2}$ sayısal değerleri içeren soruları sormayı unutarak doğrudan $\sqrt[3]{x^{3}}$ gibi içerisinde cebirsel ifadelerin yer aldığı köklü ifadelere yönelik soruları sormuştur. Ali'nin bu yaklaşımı öğrencilerin süreç içerisinde zorlanmalarına ve daha çok soru sormalarına neden olmuştur.

Araştırma dersinin planlarken üslü ifadeler ile köklü ifadeler arasındaki ilişkinin nasıl kurulacağı üzerine ayrıntılı konuşmadıklarından Ali dersinde bu ilişkiyi planda yer aldığı şekli ile kurala dayalı bir anlatımla öğrencilerine açıkladı. Öğrenciler bu anlatım ile köklü ifadelerin sadece üslü ifadelerin farklı bir yazımı olduğu fikrini edinmişler ve iki ifade arasındaki ilişkiyi anlayamamışlardır. Ali'nin bu açıklamalarını gösteren kesit aşağıdaki gibidir:

Ali: $\quad$ Bunun bir de farklı bir yazllımı var. Bu $8,8^{1}$ ya üslü biçimde yazarsan bunu $8^{\frac{1}{3}}$ olur. $\sqrt[3]{8}$ yazılımı ile şu $8^{\frac{1}{3}}$ yazılımı sadece gösterim yani başka bir şey değil, aynı şeyler. $\frac{1}{3}$ gördüğünüzde, $8^{\frac{1}{3}}$ ile $\sqrt[3]{8}$ aynı şey. Bakın burada da zaten üslü sayılardan şuna ulaşırız: 


$$
8^{\frac{1}{3}}=\left(2^{3}\right)^{\frac{1}{3}}=2^{\frac{3}{3}}=2 .
$$

Ali araştırma dersi planında olmayan bir soruyu dersinde sorarak öğrencilerin etkili bir şekilde düşünmelerini desteklemiştir. Soru dersin akışına bağlı olarak o an ortaya çıkmış ve Ali bir işlemin sonucu olarak bulunan $\sqrt[12]{2^{13}}$ ifadesinin farklı olarak nasıl yazılabileceğini sorarak öğrencilerin farklı düşünceler üretmelerine ortam hazırlamıştır. Ek olarak bu soru ile öğrencilerin yanlış fikirlerinin olduğunu fark ederek onları gidermeye çalışmıştır. Ali'nin bu sorusu ve öğrencilerle etkileşimini gösteren kesit aşağıda verilmiştir.

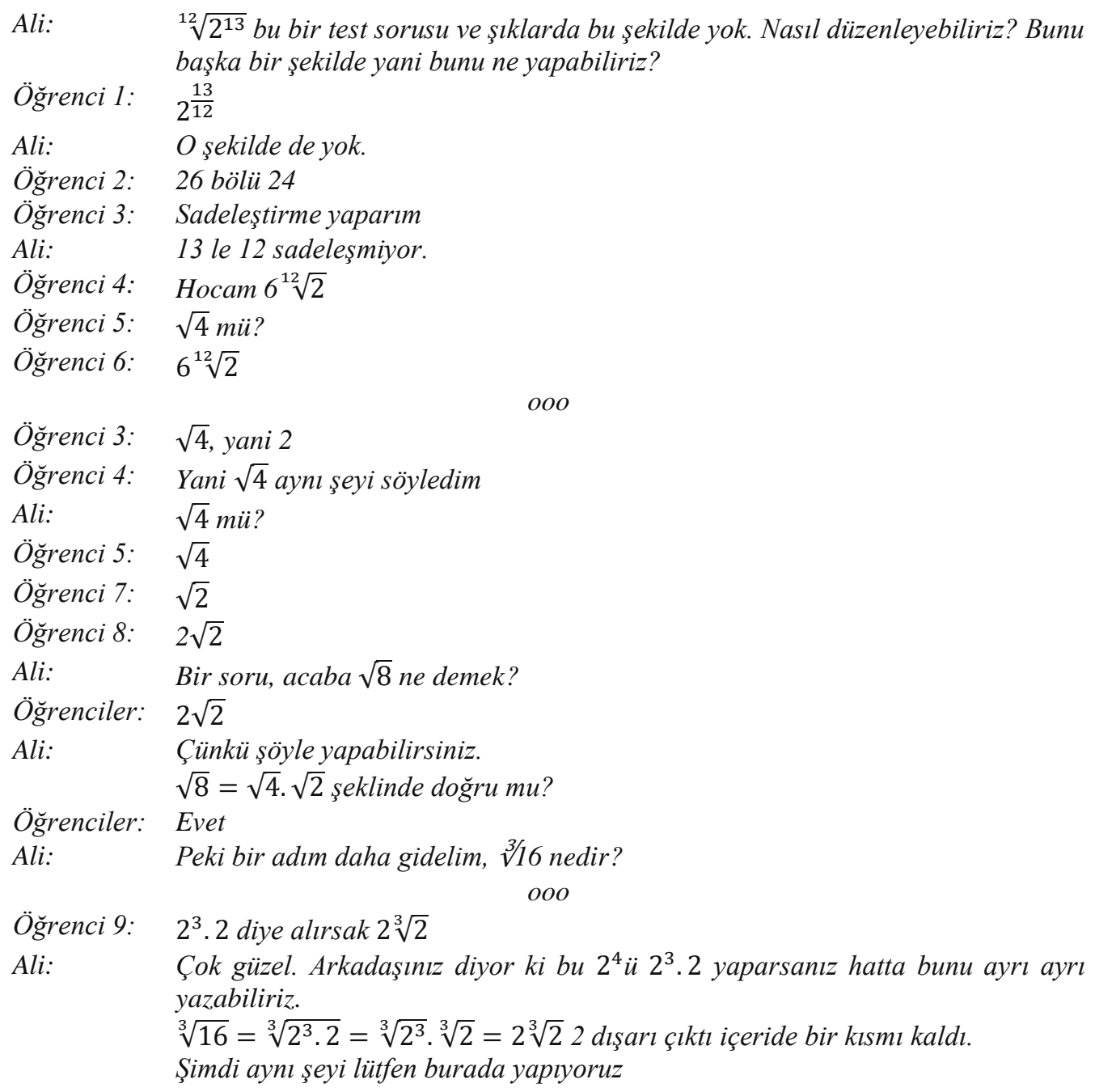

Araştırma Dersi Planı Geçiş-Geliştirme Aşamasına ilişkin Yansıtma ve Geliştirme Toplantısı Araştırma dersinde öğrenciler köklü ifadelerin formal tanımından sonra sorulan sorularda zorluklar yaşamışlardır. Bu durumu yansıtma ve geliştirme toplantısında dile getiren öğretmenler öğrencilere ilk olarak değişken içeren soruların sorulmasının anlamlı olmayacağına ve tanımı daha iyi kavrayabilmeleri için sayısal örnekleri içeren sorular sorulmasının uygun olacağına karar vermişlerdir. Bunun yanı sıra, bu eksikliğin uygulamadan kaynaklı olması sebebi ile öğretmenler plan üzerinde herhangi bir değişiklik yapmamışlardır. Planın uygulanmasındaki eksikliğe yönelik yansıtma ve geliştirme toplantısında yapılan konuşmalardan bir kesit aşağıdaki gibidir:

Özden: $\quad$ Verdiği örneklerde kökün içerisinde hep cebirsel ifadeler vardl. Reel

Ali: $\quad$ Evet, ilk sikintı orada oldu. 
Özden: $\quad$ Revizyon dersinde mutlaka sayllarla ilgili örneklerle başlayalım.

Yansıtma ve geliştirme toplantısında öğretmenler öğrencilerin üslü ifadelerle köklü ifadeler arasındaki ilişkiyi anlamadıklarını bunun yerine ezberlediklerini ve bundan farklı olarak ilişkinin kavramsal anlamayı destekleyecek şekilde verilmesini kararlaştırmışlardır. Öğretmenlerin araştırma dersinin iyileştirme ve geliştirme toplantısındaki fikirlerini gösteren bir kesit aşağıda verilmiştir.
Özden:
Üslü ifadeye çevirmenin daha anlamlı olduğu bir örnek bulmak lazım. Bu
Serin: $\quad$ Ben şöyle düşünüyorum ikisi de olabilir ama bazı yerlerde köklüden örnekler çok uygun olmadl. gitmek lazım bazl yerlerde üslüden gidilebilir.
Araştırmacı: $\quad$ Belki $3^{n}$ gibi bir yazım ile ilişkilendirmek anlamlı olabilir mi?
Özden:
Evet, oradan yapmak ilişkilendirmelerini kolaylaştırtr.

Bununla birlikte, öğretmenler $27^{x}=3$ şeklindeki bir denklem çözümünden yola çıkmanın uygun olacağına karar vermişlerdir. Böylece öğrencilerin bir önceki konuda öğrenmiş oldukları üslü ifadeleri içeren denklemlerin çözümlerine yönelik bilgilerini kullanacaklarını ve köklü ifadeler ile üslü ifadeler arasındaki ilişkiyi anlayacaklarını düşünmüşlerdir.

Plandan farklı olarak Ali'nin derste sorduğu $\sqrt[12]{2^{13}}$ ifadesinin farklı bir şekilde nasıl gösterileceği sorusunu öğretmenler yansıtma ve geliştirme toplantısında ele almışlardır. $\mathrm{Bu}$ sorunun öğrencileri düşünmeye yönlendirmesi nedeniyle etkili olduğunu ifade etmişler ve bu sorunun revizyon dersinin planına eklenmesine karar vermişlerdir. Ayrıca araştırma dersinde yer verilen içeriğin çok hızlı ve çok yoğun olduğunu yansıtma ve geliştirme toplantısında ifade eden öğretmenler üslü ifadelerle ilişkilendirme örneklerinden önce ve sonra köklü ifadelerin tarihsel gelişimi ile ilgili birtakım bilgiler vererek öğrencilerin motivasyonlarını arttırabileceklerini düşünmüşlerdir. Bununla birlikte, öğretmenler süreyle içerik arasında etkili bir düzenleme yapamadıklarını belirtmişler ve planın içeriğinin azaltılması gerektiğine değinerek bölme işlemini ve sonrasını plandan çıkararak dersin kapanışını planlamışlardır.

\section{Revizyon Dersi Planı Geçiş-Geliştirme Aşamasının Öğretimde Uygulanması}

Revizyon toplantısında karar verilen üslü ifadelerle köklü ifadelerin ilişkilendirmesine yönelik değişiklik doğrultusunda Özden ilk olarak öğrencilerine $27^{x}=3$ denkleminin nasıl çözülebileceğini sormuştur. Bu konuya ilişkin revizyon dersinde gerçekleşen süreç şu şekilde olmuştur:

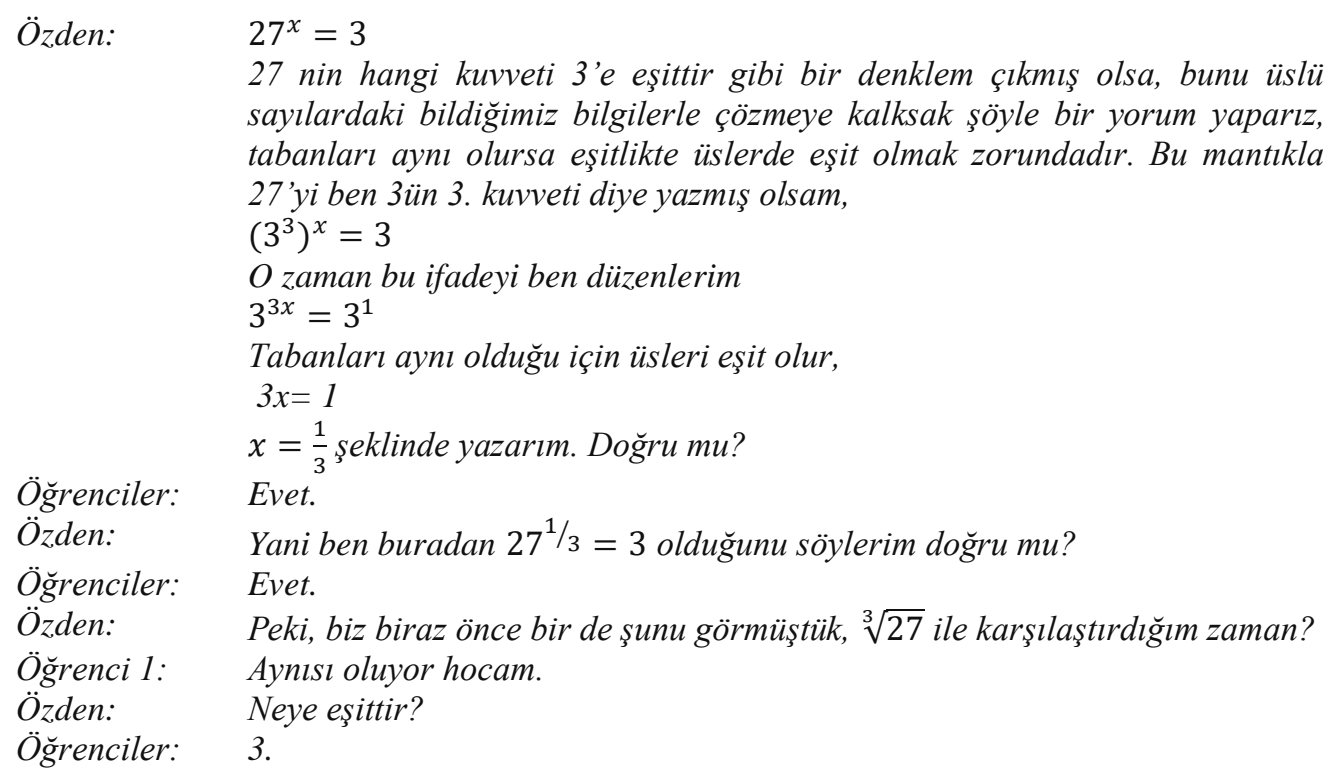


Matematik Öğretmenlerinin Ders İmecesi Kapsamında Köklü İfadelerin Öğretimine İlişkin Oluşturdukları Ders Planı

Özden: $\quad$ 'e eşittir. $\sqrt[3]{27}=3$ Yani ikisi aynı sayıya eşitse o zaman $27^{1 / 3}=\sqrt[3]{27}$ ' dir diyebilirim.

Revizyon dersinde Özden'in öğrencilerin motivasyonlarını arttırmak ve konu yoğunluğunu azaltmak amacıyla köklü ifadelerin tarihsel gelişimine yönelik bilgileri paylaştığı kesit şu şekildedir:

Özden: $\quad$ Arkadaşlar biz nasıl kareköklerin derecelerini yazarken 3, 4, 5 diye yazıyorsak mesela $\sqrt[3]{ }, \sqrt{ }, \sqrt[4]{ }$ gibi. Daha önceden bunları ifade ederlerken karekök buyken $\sqrt{ }$, küp kökü yazarlarken şu şekilde $v \sqrt{ }$ şu çizginin sayısını üçlüyorlarmış arkadaşlar.

Ögrenciler: Vaayyy.

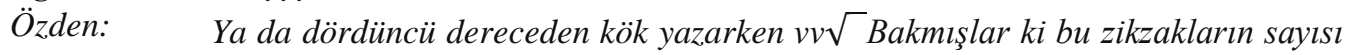
derece büyüdükçe fazlalaşıyor

Öğrenci 1: İ̧sin içinden çıkamayınca o yüzden böyle üzerine 2, 3, 4, 5 yazmaya uygun görmüşler.

oоo

Özden: $\quad$ Nicolas Chuquet bir Fransız fizikçisiymiş ve 1475 yllındayken bir cebir kitabl yayınlamış, orada rasyonel üs kullanmış. Şimdi biz biraz önce, $6^{1 / 2}$ ya da $\sqrt{6}$ yazmıştı ya $6^{1 / 2}=\sqrt{6}$

Fransız fizikçi kitabında bunu yazarken $R^{2} 6$ yani hangi sayının karesi 6 eder gibi bir yorum yapmış ya da $R^{3} 15$ gibi bir ifadeyle karşılaştığ zaman bu hangi sayının küpü 15 yani şu bizim yazdığımız $\sqrt[3]{15}$ 3.dereceden kök içerisinde 15 yerine kitabında bunu kullanmış. Sonradan bu ifadeler zamanla değişikliğe uğramış.

Öğretmenler revizyon dersinde üslü ve köklü ifadelerin ilişsisini anlamaları için yaptıkları değişikliğin öğretimi daha etkili hale getirdiğine karar vermişlerdir. Özden yansıtıcı günlüğünde bu anlatımına yönelik düşüncelerini şu şekilde belirtmiştir:

Köklü saylyı üslü sayıya çevirme kısmında anlatımda farklllık yapıldlğı için öğrencilerin anlaması daha kolay hale getirildi. Ayrica planlanan yere kadar yetişme kaygısı ikinci derste yoktu. Seçilen örneklerde düzeltmeler yapılarak ikinci ders anlatıld. Planlamadaki aksakllklar fark edildiği ölçüde giderildi. Bunların etkili olduğunu düşünüyorum. [Özden'in yansitıcı günlüğünden alınan kesit]

Revizyon dersine ilişkin yansıtma ve geliştirme toplantısında ardından öğretmenler ikinci olarak verdikleri köklü ifadelerin tarihsel gelişimine ilişkin bilginin bir bölümünü öğrencilerin ilgisini çekmediği ve düşüncelerini tetiklemediği için plandan çıkarmaya karar vermişlerdir. Ali yansıtıcı günlüğünde bunu şu şekilde dile getirmiştir:

Revizyon dersinde köklü ifadelerin tarihsel gelişimi ile ilgili küçük bilgilere yer verildi. Bu bir anlamda öğrencilerin dikkatini dağıttrken, diğer taraftan ilginç buldukları için ilgilerini çekti.[Ali'nin yansitıcı günlüğ̈̈nden alınan kesit]

\section{Ders Planı Kapanış Aşamasına Yönelik Bulgular}

Öğretmenler araştırma dersinin kapanışında planlama toplantısında öğrencilerin ders sırasında yapılanları anlayıp anlamadıklarını belirlemek için sorular sorma kararını vermişlerdir. Böylelikle tüm içeriği özetleme imkanı da bulabileceklerini ifade etmişlerdir (bkz. Tablo 6). 
Tablo 6

Araștırma Dersi Planının Kapanıș Așaması

\begin{tabular}{|c|c|c|c|c|}
\hline & Etkinlik ve Süresi & $\begin{array}{c}\text { Etkinliğin Seçilme } \\
\text { Nedeni }\end{array}$ & $\begin{array}{c}\text { Öğretmen } \\
\text { Eylemi/Rolü }\end{array}$ & $\begin{array}{c}\text { Öğrenci } \\
\text { Eylemi/Rolü }\end{array}$ \\
\hline 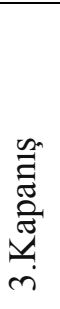 & $\begin{array}{l}\text { Soru sorma }\left(5^{\prime}\right) \\
\text { "Köklü ifadeler deyince ne } \\
\text { anliyorsunuz?" }\end{array}$ & $\begin{array}{l}\text { Öğrencilerin ders } \\
\text { boyunca neleri } \\
\text { anlayıp } \\
\text { anlamadıklarını } \\
\text { ortaya çıkarmak } \\
\text { ve anlayışlarını } \\
\text { değerlendirmek }\end{array}$ & $\begin{array}{l}\text { Öğrencilerin } \\
\text { fikirlerini ortaya } \\
\text { çıkarmak için } \\
\text { sorular sorar. }\end{array}$ & $\begin{array}{l}\text { Öğretmenin } \\
\text { sorularına yanıt } \\
\text { verir ve } \\
\text { arkadaşlarının } \\
\text { fikirlerini aktif } \\
\text { bir şekilde } \\
\text { dinler. }\end{array}$ \\
\hline
\end{tabular}

Araştırma dersinde içerik yetiştirilemediği için kapanış aşamasının uygulaması gerçekleştirilememiştir. Hatta öğretmenler araştırma dersi planının içeriğini azaltmalarına rağmen revizyon dersinde de köklü ifadelerle çarpma işlemi yapılamamış ve kapanış aşaması gerçekleştirilememiştir. Bu sebepten öğretmenler revizyon dersi sonrasında plandan çarpma işleminin de çıkarılması gerektiğine karar vererek kapanışı $\sqrt[12]{2^{13}}$ ifadesinin farklı gösterimlerinin nasıl olabileceği sorusunu öğrencilere yönlendirerek yapılmasını kararlaştırmışlardır ve planın son halini (bkz. Ek B) düzenlemişlerdir. Ders imecesi modeline ilişkin öğretmenlerin fikirlerini gösteren yansıtıcı günlüklerinden alınan örnek kesitler aşağıdaki gibidir:

Gözlem yaparken ögretmene ve ögrenciye aynı taraftan bakmak, ikisini de aynı anda görmek ilginçti. Kendi eksikliklerimizi (ögrenci yaklaşımı, ders işleyiş, seçilen örnekler...) ve güzel yanlarımızı görmemizi sağladı. [Özden'in yansıtıcı günlügüünden alınan kesit]

Süreç ilerledikçe eksiklerimizi görebildiğimiz ve farkll ögrenci fikirlerini değerlendirdiğimiz için oldukça farklı bir çalışma oldu. [Ali'nin yansitıcı günlügünden alınan kesit]

Böyle bir süreç olması hepimiz için çok güzel oldu bence. Birlikte bir dersi planlamak ve uygulamak daha fazla düşündürüyor. Ama daha yorucu bir süreç, daha fazla çalıșmamızı gerektiriyor. Ben plan yapmiyordum, planın önemini fark ettim. [Serin'in yansitıcı günlügünden alinan kesit]

Dersi anlatan öğretmen doğal ders ortamını yakalayamadı. Öğretmen ve ögrrenciler çok rahat değildi diyebiliriz. İlk ders anlatan ögretmende yetiştirme kaygısı yaşandl. [Özden'in yansitıcı günlüğ̈̈nden alınan kesit]

Dersi bu şekilde planlamak güzeldi ama dersi ilk anlatan olmam nedeniyle heyecan yaşadım. Ama dersime iliş̧kin diğer öğretmenlerden güzel dönütler almak hoşuma gitti. [Ali'nin yansitıcı günlügünden alınan kesit]

Öğretmenlerin araştırma ve revizyon dersi için hazırlanan planlara, gerçekleştirilen uygulamalara ve yapılan değişikliklere ilişkin yansıtıcı günlüklerini kapsamında değindikleri düşünceleri şu şekildedir:

Ders planında olmayan bir örneğe yer verdiğimden dolay bir kopuşs söz konusu oldu ayrıca ders planı çok uzun olduğu için yetişmedi. Bu yüzden araştırma dersi için hazırlanan plan tam olarak uygulanamadı... Süreçteki ilk planı iyi hazırladığımızı düşünmüş̧ük ancak olumsuz olarak süresine uygun bir plan değildi ve bazı anlatımlar ögrencilerin anlamasını zorlaştırdı. Revizyon dersinde farkl olarak, içerik olarak klsaltıld, birinci planda olmayıp araştırma dersinde kullanilan bazı örnekler kullanıldı. Plan içeriğinin azaltılması revizyon dersinin daha anlaşılır olmasını ve verimli olmasını sağladı. [Ali'nin yansitıcı günlügünden alınan kesit]

Köklü ifadelerde negatif ve pozitif kökün ne şekilde verilmesi gerektiğine karar vermemiz için araştırma ve revizyon derslerini ayrı ayrı gözlemlememiz iyi oldu. Daha önceden fark etmediğimiz küçük ayrıntıların aslında ögrencilerin öğrenmeleri için ne kadar önemli olduğunu anlamış olduk... Planda olmayıp ders esnasında Ali hocanın uyguladı̆̆ sorulardan etkili olanlarl sonraki dersin planına ekleyebilme şansımız oldu. [Serin'in yansitıcı günlügünden alınan kesit]

Planlama aşamasında, kuvvet alma işleminin fonksiyon olduğunu düşünerek, kök alma işleminin bu fonksiyonun tersi olduğunu konuştuk. Tersinin tanımlı olabilmesi için de çift kuvvetlerde pozitif 
kökün alınması gerektiği konusu geçti. Bu konuda yaşanan ikilik, iki farklı konu anlatımı yapılarak gözlendi ve üzerinde tartısma imkanı bulduk. [Özden'in yansitıcı günlüğünden alınan kesit]

\section{Tartışma / Sonuç ve Öneriler}

Bir mesleki gelişim modeli olan ders imecesi kapsamında üç matematik öğretmeni ile köklü ifadelere ilişkin iki ders saatlik öğretimi planlama ve uygulama çalışmalarının döngüsel olarak gerçekleştirildiği bu çalışmada köklü ifadelerin öğretiminde kullanılabilecek bir ders planı ortaya çıkarılmıştır. Öğretmenler ders imecesinin ilk araştırma dersini planlamak için iki kez toplanmışlar ve bu toplantılardan ilkinde yeterince üretken olamamışlardır. Kavramın öğretiminden çok kavrama odaklanmışlar ve dersin içeriğini belirlerken ders kitabındaki konu sıralamasını temel almışlardır. İkinci kez yaptıkları toplantı ile planı tamamlayan öğretmenler ders imcesi öncesinde öğretimlerini gerçekleştirirken plan yapmadıkları için ders planını hazırlama aşamasında daha çok içeriğin sıralanması üzerine konuşmuşlardır. Ancak öğrencilerin yapabilecekleri olası hataların ya da yaşayabilecekleri zorlukların üzerine ayrıntılı konuşmamışlardır. Araştırmacıların sağlamış oldukları öğretim araçlarından ve kaynaklardan öğretim süreçlerinde nasıl yararlanabileceklerini ve bu araçların öğrencilerin öğrenmelerini ne şekilde destekleyebileceğini tartışmamışlar bunun yerine kaynaklarda dikkatlerini çeken kavrama ilişkin özelliklere odaklanmışlardır. Ele alacakları konuları öğrencilerin rahatlıkla anlayabileceklerini ve sıkıntı yaşamayacaklarını dile getirmişlerdir. Ders kitabında yer alan pozitif karekök ve negatif karekök ifadelerinin doğru olup olmadığına karar veremedikleri ve öğrencilerin de kafa karışıklığı yaşamamaları için araştırma dersi planına dâhil etmemişlerdir. Araştırma dersinde öğrenci-öğretmen etkileşimlerinde ortaya çıkması üzerine daha ayrıntılı tartıştıkları bu hususu ders kitabında ele alındığı şekliyle öğretime entegre etmenin doğru olmadığını düşünmüşler ve negatif/pozitif kök vurgusunu ön plana çıkarmışlardır. Bu yaklaşım Roach, Gibson ve Weber (2004), Crison (2012) ve Grosser-Clarkson'un (2015) da belirttiği gibi köklü ifadelerin öğretiminde ve farklı kavramlarla ilişkilendirilmesinde uygun bir yaklaşım olmuştur. Revizyon dersinin öğretimi esnasında karesi aynı sayıya eşit olan sayı vurgusu uygun şekilde yapılırken öğretmenin yanlış ifadelerinin olduğu da görülmüştür. Bu bağlamda öğretmenlerin derste kullandıkları ifadelerin doğruluğuna da dikkat etmeleri gerektiği düşünülmektedir. Ayrıca araştırma dersi planında ele alınmayan bu durum revizyon dersinin planına dahil edilmiş olsa da öğrencilerin araştırma dersinde de bu ifadeler üzerine düşünmelerinin ve bildikleri kavramlarla ilişkilendirme yapmalarının sağlanmasının uygun olacağ 1 düşünülmektedir. Ders imecesinin doğası gereği araştırma dersi için hazırlanan plan sonraki aşamalarda değerlendirilip revize edildiği için, ilk plan ders imecesi döngüsü için büyük önem taşımaktadır. Öğretmenlerin ilk planı hazırlarken kavram üzerine daha fazla zaman ayırmaları ve kavramları daha çok tartışmaları sürecin beklenilen durumlarından biridir. Aynı zamanda ilk planın hazırlanmasında olabildiğince kaynak ve materyal desteği de araştırmacılar ya da uzmanlar tarafindan öğretmenlere sunulmalıdır. Öğretmenler kaynakları ayrıntılı bir şekilde incelemeleri ve kullanmaları konusunda planlama aşaması boyunca desteklenmelidirler. Bununla birlikte, öğretmenlere farklı kaynaklara ulaşmaları için yönlendirmeler yapılabilir. Ancak, ögretmenler ellerinde hazır bulunan materyalleri kullanma eğiliminde olma, yoğun ders saatleri içerisinde araştırma yapamayacaklarını düşünme, farklı dillerde yazılmış/hazırlanmış materyallere karar verememe ve güncel matematik eğitimi yayınlarından (kitap, makale vb.) haberdar olmama gibi gerekçelerle araştırma yapmaya yönelmeyebilmektedirler. Bu bağlamda, ögretmenlere yenilikleri takip etme ve güncel yayınlara ulaşma yönünde motivasyon sağlama yolları araştırılabilir. Özellikle ülkemizdeki öğretmenlerin bu tür dışsal motivasyonlara ihtiyaç duydukları düşünülmektedir.

Süreç boyunca gerçekleştirilen planlama toplantılarında yoğun bir ders içeriğinin öğretimini gerçekleştirebileceklerini konuşan öğretmenler öğretimde yaşanan sıkıntıları gözlemledikten sonra içeriğin azaltılmasının ve değişmesinin gerektiğine karar vermişlerdir. Bu sıkıntılarının yaşanma nedenlerinden biri öğretmenlerin geleneksel olarak yürüttükleri derslerin etkisinde kalarak içeriği yoğun tutmalarıydı. Benzer şekilde Bütün (2015), öğretmen adayları ile gerçekleştirdiği çalışmasında öğrencilerin ön bilgilerindeki eksikliklerinden ve ders esnasında 
planda olmayan uygulamalardan kaynaklı planın içeriğinin yetiştirilemediği sonucuna ulaşmıştır. $\mathrm{Bu}$ kararları vermede, öğretim sürecindeki gözlemleri ve derslerden sonra birbirleriyle gerçekleştirdikleri tartışmalar etkili olmuştur. Tartışmalarda özellikle öğrencilerin araştırma dersinde sıkıntı yaşadıklarını düşündükleri noktalara değinmeleri revizyon dersinde bu zorluklarla karşılaşmamalarını sağlamıştır. Perry ve Lewis (2008) ders imecesine katılan öğretmenlerin sürekli olarak yansıtma ve tartışma süreçlerini gerçekleştirmeleri ile öğrencilerin zorlukları, hataları ve düşünceleri üzerine daha fazla odaklanmaya başladıklarını belirtmişlerdir. Bunun yanı sıra toplantılarda yapılan tartışmalar öğretmenlerin alan bilgilerini gözden geçirmelerini sağlamış ve bu bilgilerini geliştirmelerini desteklemiştir. Araştırma sürecinde sırasıyla, öğretmenlere ders planı kılavuzu ve materyal sağlama, planlama sürecini izleme, sürece ilişkin öneriler sunma, dersleri gözlemleme, öğretmenlerin gözlemlerini etkili bir şekilde tartışmalarını sağlama ve fark edemedikleri hususları dile getirme gibi aşamalarla gerçekleştirilmesi planlanan destek öğretmenlerin öğrenci düşüncesi bilgilerinin geliştirilmesine yönelikti. Bunun yanı sıra süreç içerisinde de ele alınan kavramlarla ilgili öğretmenlerin kavramları irdeleyerek alan bilgilerini geliştirebilecekleri çeşitli firsatlar ortaya çıkmıştır. Bu bağlamda gerçekleştirilecek bir ders imecesinde ortaya çıkabilecek firsatların değerlendirilerek sürecin daha verimli hale getirilebileceği unutulmamalıdır. Çalışmada özellikle araştırmacıların desteğiyle öğretmenlerin gerçekleştirdikleri tartışmalar öğretmenleri kavramların kritik noktaları üzerine derinlemesine düşünmeye teşvik etmiştir. Wilson (2004) mesleki gelişim programlarında öğretmenlerin alan ve alanı öğretme bilgilerine aynı ölçüde önem verilmesi gerektiğini vurgulamıştır. Lewis, Perry ve Hurd (2009) öğretmenlerin ders imecesinden sadece matematiği öğretmeye ilişkin değil aynı zamanda matematiğe ilişkin bilgilerini geliştirmek amacıyla yararlandıklarını belirtmişlerdir. Planlama toplantısında öğretmenlerin öğrencilerin ön öğrenmelerine ilişkin bilgilerinin tam olduğu görülmüştür. Ancak öğretim programı ile ilgili yapılan tartışmalar öğretmenlerin öğretim programı bilgilerinde eksikliklerin olduğunu ortaya çıkarmıştır. Öğretmenler daha öncesinde planlama yapmadıkları için dokuzuncu sınıf düzeyinde genellikle hangi konuların yer verildiğine ve nelerin yeni programa eklenip çıkarıldığına bakmak için öğretim programını incelemişlerdir. Öğretim programının içeriğine uygun hazırlanan ders kitaplarını konuların sıralanışına göre takip etmek daha kolay olduğu için öğretmenler ders kitaplarından yararlanmayı tercih etmişlerdir. Bunun yanı sıra ders planı kılavuzunda yer alan sorular öğretmenlerin öğretim programını kullanmalarına ve farklı sınıf düzeylerindeki kazanımlarla planda yer verdikleri içeriği ilişkilendirmelerine teşvik etmiştir. Ek olarak, kılavuz, öğretmenlerin, öğretim sürecinin amaçlarını belirleme, öğrencilere kazandırılması gereken becerileri dikkate alma, ilgili kavramları ilişkilendirme, ön öğrenmeleri dikkate alma, kavrama geçişte ön öğrenmelerden yararlanma, gerçekleştirilecek etkinlikleri planlama, kullanacak materyalleri ve sorulacak soruları belirleme, öğrencilerin etkinlik kapsamında geliştireceği düşünceleri göz önüne alma, ortaya çıkabilecek olası kavram yanılgılarını/hataları/zorlukları ele alma, sınıf tartışması yaratma ve öğrenci düşüncelerini genişletme gibi durumlara odaklanmalarını sağlamıştır.

Araştırma ve revizyon derslerini gözlemlemek öğretmenlerin farklı açılardan dersleri değerlendirebilmelerine imkan vermiştir. Farklı deneyimlere ve alışkanlıklara sahip olan öğretmenler gerçekleştirilen öğretim süreçlerinde öğrencileri daha iyi gözlemlemişler ve bu gözlemlerine dayalı revizyon toplantılarında değerlendirmeler yapmışlardır. Öğrencilerden gelen yanıtları da derslerden sonra ele alarak revizyon dersini şekillendirmede kullanmışlardır (örn. pozitif/negatif kök, üslü-köklü ifadelerin ilişkilendirilmesi vb.). Bu doğrultuda, ders imecesinin gözlemleme aşamasının, öğretmenlerin öğrencileri ve öğrencilerin anlamalarını dikkate almalarını destekleyen bir süreç olduğu ortaya çıkmıştır. Olson, White ve Sparrow (2011) ders imecesi kapsamında gerçekleştirdikleri öğretimlerde öğrencilerin sorulan sorulara verdikleri yanıtlarını dinleyerek ve bu yanıtlarını inceleyerek öğretimsel kararlar verdiklerini ifade etmişlerdir. Bunun yanı sıra, öğrencilerin matematiksel bilgilerinin gelişimini de dikkate alan öğretmenler ileriye dönük olarak öğrencilerin yanlış genellemeler yapmalarına ve olası kavram yanılgılarına sahip olmalarına neden olabilecek durumları da ele almışlardır. Bu bağlamda, $\sqrt{-4}$ 
sayısının reel sayı olmamasının yanı sıra bu gibi sayıların ileriki sınıf düzeylerinde karşılaşabilecekleri bir kavramla ilişsi olduklarını dile getirmişlerdir. Aynı zamanda öğrencilerin kümelerde görmüş oldukları gösterimleri kullanarak onların kavramlar ve gösterimler arasında ilişki kurmalarını desteklemişlerdir.

Öğretmenler bu süreçte ders içeriğinin basitten karmaşı̆̆a olacak şekilde yapılandırılmasının öğrencilerin anlamaları için önemli olduğunu vurgulayarak bunu revizyon dersinin öğretimine yansıtmışlardır. Bu yaklaşım da öğrencilerin daha kolay anlamalarını sağlamıştır. Köklü ifadelerin öğrenilmesinde önemli bir ilişkilendirme olan üslü ifadelerle köklü ifadelerin ilişkisi üzerine araştırma dersinde kurala dayalı ve ezber gerektiren bir yaklaşımdan yararlanılmasının uygun olmadığına karar veren öğretmenler revizyon dersinde akıl yürütmeye dayalı bir yaklaşım gerektiren öğretime yer vermişlerdir. Öğrencilerin bu iki kavramı ilişkilendirmesinde ve akıl yürütmesinde etkili olan bu değişiklik, planın geliştirilmesini sağlamış, kavramları ilişkilendirmeyi sağlayarak kavramsal anlamayı desteklemiş ve yansıtma ve geliştirme toplantılarının önemini ortaya çıkmıştır. Bunlara ek olarak, öğretmenler kavramların tarihsel gelişim sürecini içeren bilgilerin öğrencileri derse motive etmedeki etkisi üzerine hemfikir olmamışlardır. Ancak hazırlanan planın uygulanmasında planı uygulayacak öğretmenin görüşünün ve inanışlarının planın içeriğini şekillendirmede diğer öğretmenlere göre daha etkili olduğu özellikle tarihsel gelişim bilgilerinin tercih edilip edilmemesinin nedeni olarak söylenebilir. Dolayısıyla dersi gerçekleştirecek olan öğretmenin gruptaki diğer öğretmenlerin görüşlerinin aksini düşündügü ve görüşlerinde kararlı davrandığı hususlar ders imecesi süresince farklı dersler kapsamında yer verildiğinde öğretmenler sahip oldukları ön yargıları değerlendirme imkanı bulacaklar ve içeriğin etkili olup olmadığı konusunda daha gerçekçi düşünebileceklerdir. Baki, Erkan ve Demir (2012) öğretmenlerin yeni durumları benimsemelerinde ve kendi öğretimlerine yansıtmalarında ders imecesinin destek olduğunu ifade etmişlerdir.

Öğretmenlerin öğretimi birlikte planlama, öğretimi gözlemleme ve öğretim üzerine yansıtmalar yapmalarını tekrarlayan döngüsel bir süreç halinde gerçekleştirmeleri oluşturdukları ders planının etkililiğgini arttırmıştır. Öğretmenlerin birlikte çalışarak gelişimlerini destekledikleri bir model olan ders imecesi kapsamında hazırlanan ders planları öğretim süreçlerinin konu odaklı olmasından çıkarılmasını ve ögrencilerin temel alınarak şekillendirilmesini sağlamıştır. Süreç sonucunda hazırlanan köklü ifadelere ilişkin ders planının özellikle geleneksel sınıf ortamlarının hakim olduğu ögretim süreçlerine destek olacağ söylenebilir. Plan farklı sınıflarda uygulanarak ve üzerinde tartışmalar yapılarak oluşturulduğu için ortaya koyulan planın köklü ifadelerin etkili bir şekilde öğrenilmesini destekleyeceği düşünülmektedir. Buna ek olarak, planlama kılavuzu ve kılavuzda yer alan sorular, farklı kavramların öğretimini planlama ve planı uygulamada öğretmenlere yol gösterici olacaktır. Ayrıca söz konusu plan farklı çalışmalar kapsamında incelenerek içeriği daha ayrıntılı hale getirilebilir.

Gerçekleştirilen ders imecesi süresince birtakım sıkıntılar ve zorluklarla karşılaşılmıştır. Öğretmenler daha önceden ders imecesine ilişkin herhangi bir deneyim yaşamadıkları için başlangıçta adaptasyon sorunları yaşamışlardır. Ancak öğretmenler ve araştırmacılar arasındaki olumlu etkileşim nedeniyle öğretmenlerin çalışmaya karşı motivasyonları giderek yükselmiştir. Özellikle planlama ve yansıtma aşamaları ders imecesi modelinde önemli olduğundan öğretmenlerin bu aşamalarda fikirlerini ifade edebilecekleri bir ortamda çalışmaları sağlanmıştır. $\mathrm{Bu}$ sayede, öğretmenlerin kavramlara ilişkin alan bilgilerinde birtakım eksikliklerin olmasına rağmen bu konuda çekingenlik yaşamadan kavramları tartıştıkları görülmüştür. Öğretmenlerin bu tür eksikliklerini meslektaşlarıyla ve araştırmacılarla paylaşmaları onların kendilerini geliştirebilmek için istekli olduklarını gösterirken aynı zamanda var olan sıkıntılarını aşabilmelerini sağlamıştır. Bu bağlamda yapılacak ileriki çalışmalarda öğretmenlerin sahip oldukları bilgileri paylaşmalarının gelişimlerini destekleme noktasında kritik olduğu fikri mutlaka benimsenmelidir. Ayrıca değişimin ve gelişimin kısa zamanda sağlanamayabileceği de unutulmamalıdır. Bu anlamda uzun dönemli alan gözlemlerinin yapılması öğretmenlerin mesleki gelişimlerini destekleyecektir. Dokuz aylık bir ders imecesinin ilk döngüsüne odaklanan bu çalışma oldukça yoğun ve titizlik gerektiren bir süreç olmasının yanı sıra verilerin toplanması ve eş zamanlı olarak sürekli analiz edilmesi sebebiyle iş yükünü artmıştır. Bu doğrultuda, ders 
imecesi gerçekleştirmek isteyen araştırmacıların tek başına çalışmak yerine bir araştırma grubuyla çalışmalarının gerçekleştirecekleri süreçlerin etkililiğini arttıracağı düşünülmektedir.

\section{Kaynaklar}

Baki, M. (2012). Sınıf öğretmeni adaylarının matematiği öğretme bilgilerinin gelişiminin incelenmesi: Bir Ders İmecesi (Lesson Study) çalışması (Yayımlanmamış doktora tezi). Karadeniz Teknik Üniversitesi, Trabzon.

Baki, A., Erkan, İ. ve Demir, E. (2012, Haziran). Ders planı etkililiğinin lesson study ile geliştirilmesi: Bir aksiyon araştırması. X.Ulusal Fen Bilimleri ve Matematik Eğitimi Kongresi, Niğde Üniversitesi, Niğde.

Baki, M. ve Arslan, S. (2015). Ders imecesinin (lesson study) sınıf öğretmeni adaylarının matematik dersini planlama bilgilerine etkisinin incelenmesi. Türk Bilgisayar ve Matematik Ë̆itimi Dergisi, 6(2), 209-229.

Ball, D., Sleep, L., Boerst, T. ve Bass, H. (2009). Combining the development of practice and the practice of development in teacher education. The Elementary School Journal, 109(5), 458-474.

Borko, H. (2004). Professional development and teacher learning: Mapping the terrain. Educational Researcher, 33(8), 3-15.

Borko, H. ve Livingston, C. (1989). Cognition and improvisation: Differences in mathematics instruction by expert and novice teachers. American Educational Research Journal, 26, 473-498.

Bütün, M. (2012). Illköğretim matematik ögretmeni adaylarının uygulanan zenginleștirilmiş program sürecinde matematiği ögretme bilgilerinin gelişimi (Yayımlanmamış doktora tezi). Karadeniz Teknik Üniversitesi, Trabzon.

Bütün, M. (2015). Öğretmenlik uygulaması dersinde ders imecesi modelinin değerlendirilmesi: Sorunlar ve çözüm önerileri. Adıyaman Üniversitesi Ĕ̈itim Bilimleri Dergisi, 5(2), 136167.

Crison, C. (2012). What is the square root of sixteen? Is this the question? Mathematics Teaching, 230(1), 21-22.

Erlandson, K. M. (2013). A study of college students' misconceptions of radical expressions. Unpublished master thesis). SUNY College at Fredonia.

Fernandez, C. (2002). Learning from Japanese approaches to professional development: The case of lesson study. Journal of Teacher Education, 53(5), 393-405

Fernandez, C., Yoshida, M., Chokshi, S. ve Cannon, J. (2001). An overview of lesson study. Erişim adresi: http://www.teacherscollege.edu/lessonstudy/presentations_slides.html

Fischbein, E., Jehiam, R. ve Cohen, D. (1995). The concept of irrasyonel numbers in high school students and prospective teachers. Educational Studies in Mathematics, 29(1), 29-44.

Gómez, B. ve Buhlea C. (2009). The ambiguity of the $\sqrt{ }$ sign. Proceedings of the Sixth Congress of The European Society for Research in Mathematics Education. (CERME 6), Lyon, France.

Grosser-Clarkson, D. L. (2015). The root of the problem. Mathematics Teacher, 109(2), 98-102.

Güven, B., Çekmez, E. ve Karataş, İ. (2011). Examining preservice elementary mathematics teachers' understandings about irrational numbers. PRIMUS: Problems, Resources, and Issues in Mathematics Undergraduate Studies, 21(5), 401-416.

İsleyen, T. ve Mercan, E. (2013). Examining the difficulties experienced by 8th grade students on the subject of square root numbers. Eğitimde Kuram ve Uygulama, 9(4), 529-543.

Jones, K. (2005). Planning for mathematics learning. S. Johnston-Wilder, P. Johnston-Wilder, D. Pimm, ve J. Westwell, (Yay. Haz.), Learning to Teach Mathematics in the Secondary School (2nd edition ) içinde (s.93-113). London: Routledge.

Kagan, D. ve Tippins, D. (1992). The evolution of functional lesson plans among twelve elementary and secondary student teachers. The Elementary School Journal, 92, 477-489. 
Lesson Study Research Group. (2013). What is lesson study? Erişim adresi: http://www.tc.columbia.edu/lessonstudy/lessonstudy.html.

Lewis, C. (2002). Does lesson study have a future in the United States? Nagoya Journal of Education and Human Development, 1(1), 1-23.

Lewis, C. C., Perry, R. R. ve Hurd, J. (2009). Improving mathematics instruction through lesson study: A theoretical model and North American Case. Journal of Mathematics Teacher Education, 12(4), 285-304.

Lewis, C. C., Perry, R. R. ve Hurd, J.(2004). A deeper look at lesson study. Educational Leadership, 61(5), 18-22.

Lewis, C., Perry, R. ve Murata, A. (2006). How should research contribute to instructional improvement? The case of lesson study. Educational Researcher, 35(3), 3-14.

Lloyd, G., M. ve Behm, S. L. (2005). Preservice elementary teachers' analysis of mathematics instructional materials. Action in Teacher Education 26(4), 48- 62.

McCutcheon, G. (1980). How do elementary school teachers plan? The nature of planning and influences on it. Elementary School Journal, 8, 4-23.

Milli Eğitim Bakanlığı [MEB]. (2013a). Ortaöğretim matematik dersi (9-12. Sinıflar) öğretim programı. Ankara: Devlet Kitapları Müdürlüğü Basımevi.

Milli Eğitim Bakanlığı [MEB]. (2013b). Ortaokul matematik dersi (5, 6, 7 ve 8. sinıflar) öğretim programı. Ankara: Devlet Kitapları Müdürlüğü Basımevi.

Murata, A. (2011). Conceptual overview of lesson study: Introduction. L. Hart, A. Alston ve A. Murata (Yay. haz.). Lesson Study Research and Practice in Mathematics Education: Learning Together içinde (s.1-12). NY: Springer.

Mutton, T., Hagger, H. ve Burn, K. (2011). Learning to plan, planning to learn: The developing expertise of beginning teachers. Teachers and Teaching: Theory and Practice, 17, 399416.

Olson, J.C., White, P. ve Sparrow, L. (2011). Influence of lesson study on teachers' mathematics pedagogy. L. C. Hart, A. S. Alston ve A. Murata, (Yay. haz.), Lesson study Research and Practice in Mathematics Education içinde (s.39-59). New York: Springer.

Ontario Ministry of Education. (2006). A Guide to effective instruction in mathematics: kindergarten to grade 6 - Volume One. Erişim adresi: http://eworkshop.on.ca/edu /resources/guides/Guide_Math_K_6_Volume_1.pdf

Özkan, E. (2011). Misconceptions in radicals in high school mathematics. Procedia-Social and Behavioral Sciences, 15(1), 120-127.

Perry, R. R. ve Lewis, C. C. (2008). What is successful adaptation of lesson study in the US? Journal of Educational Change, 10(4), 365-391.

Roach, D., Gibson, D. ve Weber, K. (2004). Why is square root of 25 not plus or minus 5 ?. Mathematics Teacher, 97(1), 12-13.

Rowland, T., Turner, F., Thwaites, A. ve Huckstep, P. (2009). Developing primary mathematics teaching: Reflecting on practice with the Knowledge Quartet. London: Sage.

Schoenfeld, A. H. (2005). On learning environments that foster subject-matter competence. L. Verschaffel, E. De Corte, G. Kanselaar ve M. Valcke (Yay. haz.). Powerful environments for promoting deep conceptual and strategic learning içinde (s. 29-44). Leuven, Belgium: Studia Paedagogica.

Smith, M. S., Bill, V. ve Hughes, E. K. (2008). Thinking through a lesson: Successfully implementing high-level tasks. Mathematics Teaching in the Middle School, 14(3), 132138.

Stigler, J. W. ve Hiebert, J. (2016). Lesson study, improvement, and the importing cultural routines. ZDM Mathematics Education, 48(4), 581-587.

Stigler, J. ve Hiebert, J. (1999). The teaching gap. New York: The Free Press.

Swearingen, M. (2014). Four Preservice Teachers' Use of Mathematical Knowledge during Lesson Planning and Instruction in the Field Experience. (Unpublished doctoral dissertation). University of San Francisco. 
Takahashi, A. (2014). The role of the knowledgeable other in lesson study: Examining the final comments of experienced lesson study practitioners. Mathematics Teacher Education and Development, 16(1), 4-21.

Takahashi, A. ve Yoshida, M. (2004). Ideas for establishing lesson-study communities. Teaching Children Mathematics, 10(9), 436-443.

Verhoef, N., Tall, D., Coenders, F. ve Van Smaalen, D. (2013). The complexities of a lesson study in a dutch situation: Mathematics teacher learning. International Journal of Science and Mathematics Education, 12(4), 859-881.

Walker, E. (2011). How "language-aware" are lesson studies in an East Asian high school context? Language and Education, 25(3), 187-202.

Wilson, S. M. (2004). Foreword. S. Cohen (Yay. haz.), Teachers' professional development and the elementary mathematics classroom: Bringing understandings to light içinde (s. ixxii). Lawrence Erlbaum Associates, Publishers. Mahwah, New Jersey. London.

Yıldırım, A. ve Şimşek, H. (2011). Sosyal bilimlerde nitel araştırma yöntemleri (8. Baskı). Ankara: Seçkin Yayıncılık.

Yoshida, M. (1999). Lesson study: A case study of a japanese approach to improving instruction through school-based teacher development (Unpublished $\mathrm{PhD}$ ). University of Chicago.

Zazkis, R. ve Sirotic, N. (2004). Making sense of irrational numbers: Focusing on representation. M. J. Hoines, A. B. Fuglestad (Yay. haz.), Proceedings of 28th International Conference for Psycholog of Mathematics Education, 4, 497-505, Bergen, Norway.

\section{Extended Abstract \\ Introduction}

Lesson study is a professional development model which teachers collaboratively and systematically implement practices involving planning, implementation, observation and discussion of lessons (Lesson Study Research Group, 2013). In the lesson study, lessons are planned by considering the students' thoughts and learning processes and teaching is realized in accordance with these plans. In this context, one of the main components of the lesson study, which is a cyclical process, is lesson plans. In this process, which teachers worked collaboratively, the effectiveness of the teaching is increased with the plans which the teachers having different knowledge and habit prepare by discussing and evaluating their ideas. Comprehensiveness of the prepared lesson plans can prevent possible difficulties in the teaching process and help teachers guide students' learning appropriately. The plans prepared during the lesson are evaluated in the lessons and in the reflection and development meetings after the lessons. Thus, by considering all the situations that arise during the implementation of any plan, teachers reflect the necessary changes in the plan of the revision lesson and enrich their approaches about lesson planning by finding opportunities to broaden their perspectives. A lesson plan is a guide that determines how a lesson's flow will be shaped. The lesson plan is a reminder tool for teachers to take place activities before and during the lesson and generally includes the lesson's products, learning activities which are ordered in a logical way, assessment activities and assessment criteria (McCutcheon, 1980). In this study, the lesson plans for the radical expressions prepared in the first cycle of the lesson study consisting of three cycles realized during nine months for the improvement of three mathematics teachers' knowledge of student thinking were examined. While realizing the lesson study cycles, a five-step process was adopted. While forming the stages of the process, it was used from the lesson study cycles and steps lesson study cycles expressed by Yoshida (1999), Lewis, Perry and Murata (2006) and Stigler and Hiebert (1999) and these stages were explained by the researchers. In this direction, the teachers completed a lesson study cycle by following five steps as research and planning, implementing research lesson, reflecting and improving research lesson, implementing revision lesson and reflecting and improving revision lesson throughout the process. Also, the researchers presented a lesson plan guide (Smith, Bill \& Hughes, 2008) translated and revised from literature to the teachers. The teachers used the lesson plan guide while planning the lessons. This guide allowed teachers to focus on their students and students' thinking throughout the process. In this study, the plans of the lessons in 
the first cycle were handled which the teachers decided for the students to gain the learning outcomes of "Explains the radical expressions, specifies the their properties and makes practices." and "Explains the rational number power of a real number with examples, shows the properties of the radical expressions by using the features of the exponential expressions and applies about them." at the 9th grade. In this direction, the aim of the study is to examine the lesson plans prepared and revised for teaching of the introduction part of the radical expressions at the 9th grade by the three mathematics teachers participating in the lesson study cycles. While evaluating the lesson plans, examinations were carried out for the three sections of the lesson plan guide, and the revised parts and the reasons of these revisions were tried to explain in detail. In this context, the research questions to be responded are as follows:

1. How is the phase of getting started in the lesson plan structured during the lesson study?

2. How is the phase of working on it in the lesson plan structured during the lesson study?

3. How is the phase of closure in the lesson plan structured during the lesson study?

\section{Method}

This study is based on the qualitative case study design in order to examine the developed lesson plan of teaching radical expressions within the first cycle of the lesson study that the three mathematics teachers realized. As the lesson plans prepared by teachers and the research and revision lessons that they implemented on the plans were examined in detail, the case study design was approved. Teachers prepared a lesson plan for teaching radical expressions using a lesson plan guide that encouraged focusing on the students' thinking prepared by the researchers utilizing the literature. The plan was revised and developed by the reflections made after one of the teachers implemented the plan and the others observed the lesson by focusing on the students. The final lesson plan regarding teaching radical expressions was constructed by making the new changes in the meeting of reflection and improvement held after the implementation of the plan in the revision lesson of the lesson study.

The data of the study were obtained through group interviews in the planning and revision meetings, four-hour lesson observations, two in the research lesson and two in the revision lesson, the lesson plans of these lessons and the teachers' reflective diaries in the context of the first cycle of the lesson study. In the analysis process, the lesson plans and the teachers' expressions during the planning meetings were examined by using descriptive analysis. Two researchers analyzed the data together and they completed the analyses of the data by arriving at a consensus. While the lesson plans were examining in a detailed way, the improvement of the teachers were considered.

\section{Result and Discussion}

In this study regarding planning and implementation of two-hours teaching of the radical expressions conducted with three mathematics teachers, the lesson plan which could be used for teaching radical expressions (see Appendix B) was designed. The teachers who expressed that they could realize the teaching of the intensive lesson content during the planning meetings made throughout the process decided that they had to increase and change the content of the lesson plan. Perry and Lewis (2008) stated that the teachers participating in the lesson study came to focus on students' thinking, difficulties and errors more by realizing the reflections and discussions. Besides, the discussions in the planning meetings provided for the teachers to revise their content knowledge and supported to improve them. Especially, these discussions encouraged the teachers to think the critical points of the concepts. Observing the research and revision lessons throughout the process allowed the teachers to be able to evaluate the lessons from different perspectives. The teachers with different experiences and habits observed students during the actual teaching process better and evaluated the lessons at the revision meetings based on these observations. They used the students' responses in arranging the following lessons. Olson, White and Sparrow (2011) stated that the teachers made educational decisions by listening and examining the 
students' answers during the teaching in the context of the lesson study. The teachers decided that it was not appropriate that teaching the relation between the radical expressions and the exponential expressions were realized in the research lesson by rule based approach. In the revision lesson, the teacher taught this relation by reasoning based approach in accordance with their plan. Additionally, it was seen that the teachers disagreed that information about the historical development of the concepts made differences in the context of the lesson and supported to increase students' motivations. Teachers will have opportunities for evaluating their own bias and may think whether the content is effective more realistically in the context of the teaching in the lesson study if they differently think and are intent about their ideas. Baki, Erkan and Demir (2012) stated that lesson study supported that the teachers adopted the new situations and they reflected the differences in their teaching.

The effectiveness of the lesson plan increased due to the fact that teachers collaboratively worked in a cyclical process of planning, observing teaching, and reflecting on teaching. It can be said that the lesson plan for the radical expressions prepared as a result of the process will support the teaching processes that are dominated by the traditional classroom environments. The whole process provide the teachers to think about the aspects which they should consider in the planning process and the questions which they should respond and it will be guide for planning and implementing the lesson plan of different concepts. 
DERS PLANI KILAVUZU

\section{BÖLÜM: AMAÇLARI BELIRLEME - ETKINLIIĞI SEÇME VE DÜZENLEME}

Dersteki amacinız nedir?

- Bu derste kazandirılacak beceriler (pratikler, uygulamalar vb.) nelerdir?

- Geliştirilecek belirli stratejiler var mıdır? Açıklayınız.

- Dersteki matematiksel kavramlar nelerdir?

- Bu ders ünitenin neresinde yer almaktadır? Nedenini açıklayınız.

- Bu kavramlardan ve/ya da becerilerden herhangi birine başka bir ünitede değinilmiş midir?

- Temel amacınız olarak belirlediğiniz kavramla bu ders neleri ilişkilendirmelidir?

- Öğrenciler belirlenen amaçlara hangi etkinliklerle ulaşacaklardır?

- Etkinlikleri ya da problemleri nasıl sunmayı planliyorsunuz?

- Hangi model, öğrenme nesnesi veya görseli kullanacaksınız?

- Etkinliklerinizi öğrencilerin ön bilgilerine ne şekilde dayandırıyorsunuz?

- Söz konusu etkinliğe başlayabilmeleri için öğrencilerin hangi kavramları, fikirleri ya da anlayışları bilmeleri gerekmektedir?

- Bu sinıfta kavramla ilgili olarak önceden neler incelenmiştir?

- Bu kavramla ilişki olarak hangi bağlamları ilişkilendirebilirsiniz?

- Öğrencilerin ön bilgilerini hatırlamalarına yardımcı olmak için hangi soruları soracaksınız?

- Öğrenciler hangi fikirleri açıklayarak başlayabilirler ve hangi dili kullanabilirler?

Öğrencilerin etkinlikleri başarılı bir şekilde gerçekleştirebilmeleri sağlayan yollar nelerdir?

- Öğrencilerin hangi yöntemleri kullanacağını düşünüyorsunuz?

- Öğrencilerin sahip olabileceği kavram yanılgıları nelerdir?

- Öğrencilerin yapabileceği hatalar nelerdir?

- Öğrencilerin karşılaşacağı zorluklar ve güçlükler nelerdir?

Öğrencilerden söz konusu etkinlik üzerinde çalıştıklarında ve etkinliği tamamladıklarında beklentileriniz neler olacaktır?

- Öğrencilerin çalışmalarında hangi kaynakları ve araçları kullanmaları gerekecektir?

- Öğrenciler etkinliği gerçekleştirirken nasıl çalışacaklardır? (bireysel olarak, küçük gruplar halinde, iki kişilik çalışma gruplarıyla)

- Öğrenciler bağımsız olarak ya da küçük gruplar/çiftler halinde ne kadar süre çalışacaklardır? Öğrenciler belirli bir şekilde ortak çalıştırılacak mıdır? Öyle ise hangi yolla çalıştırılacaklardır?

- Öğrenciler çalışmalarını yazacaklar mı ve nasıl bir sunum yapacaklar (sözlü sunum, yazılı rapor vb.)?

Dersin her bölümü için ne kadar zaman gerektiğini düşünüyorsunuz?

\section{BÖLÜM: ETKINNLIK SÜRESINCE ÖĞRENCIYİ DESTEKLEME}

- Etkinliği hangi soruyla başlamayı düşünüyorsunuz?

- Öğrenciler matematiksel düşüncelerini ve anlayışlarını hangi yollarla açıklayacaklardır?

- Öğrencilerin öğrenmelerini/anlayışlarını göstermeleri için neler söylemeleri/yapmaları gerekmektedir?

- Hazır olan öğrencilere ne tür genişletmeler veya onları zorlayacak ne tür şeyler sağlayacaksınız?

• Öğrenciler bireysel olarak ya da küçük gruplar halinde çalışırlarken; 
- Üzerinde çalışılan fikirlerin vurgulanacağından ve açıklanacağından nasıl emin olacaksiniz?

- Öğrencilerin karş1lıklı saygı içerisinde birbirleriyle konuştuğundan ve birbirlerini dinlediğinden nasıl emin olacaksınız?

- Öğrencilerin düşüncelerine odaklanmak için hangi soruları soracaksınız?

- Öğrencilerin fikirler hakkında nasıl düşündüğünü öğrenmeniz için ne yapmaları ve ne söylemeleri gerekir?

- Öğrencilerin anahtar fikirlere veya problem çözme stratejilerine yönelik anlayışlarını değerlendirmek için hangi soruları soracaksınız?

- Öğrencilerin fikirlere yönelik anlayışlarını geliştirmek için hangi soruları soracaksinız?

- Öğrencilerin düşüncelerini birbirleriyle paylaşmalarına teşvik etmek için veya arkadaşlarının fikirlerine yönelik anlayışlarını değerlendirmek için hangi soruları soracaksınız?

- Zorluk yaşayacağını tahmin ettiğiniz öğrencilere nasıl yardımcı olmayı planllyorsunuz?

Öğrencilerin etkinlik ile etkin bir şekilde uğraşmaya devam ettiklerinden nasıl emin olacaksiniz?

- Bir öğrenci etkinliğe katılmaya nasıl başlayacağını bilmiyorsa neler yapacaksınız?

- Bir öğrenci etkinliği hemen bitirirse veya sıkılırsa ve rahatsız edici hale gelirse neler yapacaksınız?

- Bir öğrenci etkinliğin dersiniz ve amacınızla ilgili olmayan yönlerine odaklanırsa neler yapacaksınız?

\section{BÖLÜM: ÖĞRENCİ ÇÖZÜMLERINII PAYLAŞMA VE TARTIŞMA}

Dersin amaçlarını başarıyla tamamlayabilmek için sınıf tartışmasını nasıl düzenleyeceksiniz? Özel olarak,

- Sınıf tartışması boyunca hangi çözüm yollarını paylaşmayı isteyeceksiniz? Çözümler hangi sirayla sunulacaktır? Neden?

- Çözümlerin sunulduğu sırada dersin odağı olan fikirlere yönelik öğrenci anlayışlarının gelişmesine hangi şekilde yardımcı olacaksınız?

- Öğrencilerin

- Öğrenmelerini istediğiniz fikirleri anlamlandırabilmeleri,

- Paylaşılan çözümleri ayrıntılarıyla açıklayabilmeleri, tartışabilmeleri ve sorgulayabilmeleri,

* Sunulan farklı fikirler arasında bağlantılar kurabilmeleri,

- Sunulan fikirler ve içerikle ilgili bağlantılar kurabilmeleri için hangi özel soruları soracaksınız?

Sınıftaki öğrencilerin öğrenmelerini istediğiniz fikirleri anladıklarını ne yaptıklarında anlamış olacaksınız?

Sonraki derste bu dersin üzerine ne yapacaksınız? 
EK B. Köklü İfadelerin Öğretimine İlişskin Geliştirilen Ders Planı

\begin{tabular}{|c|c|c|c|c|}
\hline & Etkinlik ve Süresi & Etkinliğin Seçilme Nedeni & Öğretmen Eylemi/Rolü & Öğrenci Eylemi/Rolü \\
\hline 垉 & $\begin{array}{l}\text { Soru sorma }(10 ') \\
\text { - Köklü ifade ne demektir? } \\
\text { - Kök içindeki sayı hangi pozitif } \\
\text { sayının karesidir? } \\
\text { - Karesi } 4 \text { olan sayılar nelerdir? } \\
\text { - Küpü } 8 \text { olan sayı kaçtır? } \\
\text { - } \sqrt{4}, \sqrt{16}, \sqrt{-4} \text { vb. kaçtır? } \\
\text { - } x^{2}=-64 \text { eşitliğini sağlayan x } \\
\text { gerçek sayıları nelerdir? } \\
\text { - Karesi 64'e eşit olan gerçek } \\
\text { sayılar nelerdir? }\end{array}$ & $\begin{array}{l}\text { - Öğrencilerin ortaokulda } \\
\text { görmüş oldukları kareköklü } \\
\text { ifadelere ilişkin ön bilgilerini } \\
\text { ortaya çıkarmak, varsa hatalı } \\
\text { bilgilerini gidermek ve eksik } \\
\text { bilgilerini tamamlamak, ilgili } \\
\text { kavram/konu/gösterimleri } \\
\text { hatırlamalarını sağlamak ve } \\
\text { yeni konuya 1sındırmaya } \\
\text { çalışmak/ön hazırlık yapmak. } \\
\text { - Öğrencilerin negatif sayıların } \\
\text { karekökünün farklı kümelerde } \\
\text { tanımlandığı ve reel sayılarda } \\
\text { bir karşılı̆̆ının olmadığını } \\
\text { matematik diline dikkat } \\
\text { ederek tartışmak. } \\
\text { - Öğrencilerin denklem } \\
\text { çözümünden yararlanarak } \\
\text { negatif kök ve pozitif kök } \\
\text { kavramlarını } \\
\text { anlamlandırmalarını } \\
\text { sağlamak. } \\
\text { x² = 64 denkleminin kökleri } \\
\text { ile karekök ile ilişkisini fark } \\
\text { etmelerini sağlayarak olası bir } \\
\text { kavram yanılgısının önüne } \\
\text { geçmek. }\end{array}$ & $\begin{array}{l}\text { Öğrencilere belirlenen } \\
\text { soruları sorar, öğrencilerin } \\
\text { düşüncelerini ortaya } \\
\text { çıkarmaya çalışır, } \\
\text { gerektiğinde ek sorularla } \\
\text { düşüncelerini genişletir, } \\
\text { öğrencilerin hatalı/eksik } \\
\text { bilgilerini gidermeye/ } \\
\text { geliştirmeye çalışır ve ön } \\
\text { bilgilerini dikkate alarak } \\
\text { sürece yön verir. }\end{array}$ & $\begin{array}{c}\text { Soruları yanıtlar, } \\
\text { karekök kavramıyla } \\
\text { ilgili bilgilerini ifade } \\
\text { eder, arkadaşlarının } \\
\text { açıklamalarını dinler, } \\
\text { düşüncelerini } \\
\text { paylaşır ve sorulara } \\
\text { aktif katılım sağlar. }\end{array}$ \\
\hline \multirow{3}{*}{ 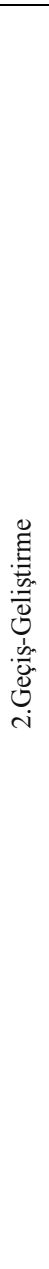 } & $\begin{array}{l}\text { Soru sorma }\left(5^{\prime}\right) \\
\text { - } \sqrt[3]{27} \text { ifadesi neye eşittir? } \\
\text { - } \sqrt[3]{-125} \text { ifadesi neye eşittir? } \\
\text { - } \sqrt[4]{256} \text { ifadesi neye eşittir? }\end{array}$ & $\begin{array}{l}\text { - Kareköklere ilişkin bilgileri } \\
\text { olan öğrencilerin mevcut } \\
\text { bilgilerini kullanarak ve } \\
\text { genişleterek karşılığı tam sayı } \\
\text { olan farklı dereceli kökleri } \\
\text { düşünmelerini desteklemek } \\
\text { ve bu örnekler yardımıyla } \\
\text { köklü ifadelere geçiş yapmak. } \\
\text { - Köklü ifadelerin tanımının } \\
\text { somutlaştırılmasını } \\
\text { sağlayacak örnekler sunmak. }\end{array}$ & $\begin{array}{c}\text { Öğrencilerin ön bilgilerini } \\
\text { kullanmalarını } \\
\text { destekleyerek mevcut } \\
\text { anlamalarını genişletmeye } \\
\text { çalışır ve köklü ifadelerin } \\
\text { tanımını anlayabilmeleri } \\
\text { için sayısal örnekler } \\
\text { sorarak öğrencileri bu } \\
\text { örneklere yönelik } \\
\text { düşündürür. }\end{array}$ & $\begin{array}{l}\text { Karekök kavramına } \\
\text { ilişkin bilgilerine } \\
\text { dayalı farklı } \\
\text { derecelerin } \\
\text { anlamlarının ne } \\
\text { olduğuna ilişkin akıl } \\
\text { yürütür, sorulara } \\
\text { aktif bir şekilde yanıt } \\
\text { verir ve gerekli } \\
\text { ilişkilendirmeleri } \\
\text { yapar. } \\
\end{array}$ \\
\hline & $\begin{array}{l}\text { - } \frac{\text { Tanımlama }}{\left(5^{\prime}\right)} \\
\text { - } n \in \mathbb{Z}^{+} \quad n \geq 2 \text { olmak üzere } \\
\text { - } \sqrt[\mathrm{n}]{\mathrm{x}^{\mathrm{n}}}= \begin{cases}\mathrm{x} & \text { n tek ise } \\
|\mathrm{x}| & \text { n çift ise }\end{cases} \end{array}$ & $\begin{array}{l}\text { - Köklü ifadeleri genelleştiren } \\
\text { tanımı yapmak ve matematik } \\
\text { dilini uygun bir şekilde } \\
\text { kullanarak kavramın anlamını } \\
\text { tartışmak. }\end{array}$ & $\begin{array}{l}\text { Farklı dereceli köklere } \\
\text { ilişkin yapılan } \\
\text { örneklendirmelerden } \\
\text { sonra öğrencilerin köklü } \\
\text { ifadeleri tanımlamalarını } \\
\text { destekler ve matematik } \\
\text { dilini etkili kullanmaları } \\
\text { için onları yönlendirir. }\end{array}$ & $\begin{array}{c}\text { Örnekleri birbiriyle } \\
\text { ilişkilendirerek köklü } \\
\text { ifadeleri genelleştirir } \\
\text { ve herhangi bir } \\
\text { dereceden kökün } \\
\text { eşitliğini açıklar ve } \\
\text { matematik dilini } \\
\text { uygun bir şekilde } \\
\text { kullanır. }\end{array}$ \\
\hline & $\begin{array}{l}\text { Soru sorma }\left(20{ }^{\prime}\right) \\
\text { Aşağıldaki işlemlerin } \\
\text { sonuçları kaçtır? } \\
\text { - } \sqrt[4]{(-16)^{2}}-\sqrt[5]{-3^{5}}+ \\
\sqrt[8]{\left(-16^{4}\right)^{2}} \\
\text { - } \sqrt{(\sqrt{5}-1)^{2}}-\sqrt{(2-\sqrt{5})^{2}} \\
\cdot x<y<0 \text { olmak üzere, } \\
\sqrt{x^{2}}+\sqrt[3]{(x-y)^{3}}-\sqrt{y^{2}} \\
\text { - } x<0<y \text { olmak üzere, } \\
\sqrt[3]{(y-x)^{3}}-\sqrt{(x-y)^{2}} \\
+\sqrt[4]{(-y)^{4}}-\sqrt[5]{(-x)^{5}} \\
\cdot a<0<b<c \text { olmak üzere, } \\
\sqrt{(a-b)^{2}}+ \\
\sqrt{b^{2}-2 b c+c^{2}}+ \\
\sqrt[3]{(a-c)^{3}} \\
\end{array}$ & $\begin{array}{l}\text { - Köklü ifadelere ilişkin } \\
\text { tanımın } \quad \text { uygulamalarını } \\
\text { yapmak ve işlemsel akıcılığı } \\
\text { sağlamak. }\end{array}$ & $\begin{array}{c}\text { Öğrencilere soruları } \\
\text { sorarak yanıtlamaları için } \\
\text { yeterli zaman verir, hatalı } \\
\text { ya da eksik çözüm yapan } \\
\text { öğrencilerin çözümlerine } \\
\text { yönelik sınıf tartışması } \\
\text { yaratarak olası tüm } \\
\text { sıkıntıların giderilmesini } \\
\text { sağlar. }\end{array}$ & $\begin{array}{c}\text { Tanımın anlamını } \\
\text { düşünerek ve mutlak } \\
\text { değer bilgilerini } \\
\text { hatırlayarak soruların } \\
\text { çözümü yapmaya } \\
\text { çalışır, arkadaşlarının } \\
\text { çözümlerini dinler ve } \\
\text { tartışma ortamına } \\
\text { aktif olarak katılır. }\end{array}$ \\
\hline
\end{tabular}




\begin{tabular}{|c|c|c|c|c|}
\hline \multirow{3}{*}{ 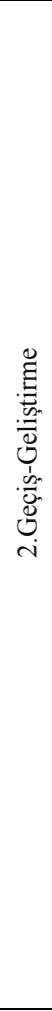 } & $\begin{array}{l}\text { Motivasyon (3') } \\
\text { Karekök simgesinin tarihsel } \\
\text { gelişimi ile ilgili bilgi vermek } \\
\quad v v v \sqrt{ }\end{array}$ & $\begin{array}{lr}\text { - Öğrencilerin } & \text { derse ve } \\
\text { kavrama } & \text { yönelik } \\
\text { motivasyonlarını } & \text { arttırmak ve } \\
\text { kavramın } & \text { anlamını } \\
\text { pekiștirmelerini } & \text { sağlayarak } \\
\text { matematiksel } & \text { düşünmelerini } \\
\text { desteklemek. }\end{array}$ & $\begin{array}{c}\text { Kök simgesi ile ilgili } \\
\text { tarihsel bilgi verir ve bu } \\
\text { sayede öğrencilerin tarihte } \\
\text { kullanılan kök simgesi ile } \\
\text { kökün anlamını } \\
\text { iliskkilendirmeleri için } \\
\text { dikkatlerini kökün zikzak } \\
\text { sayısına çeker ve kök } \\
\text { kavramına ilişkin } \\
\text { anlayışlarını destekler. }\end{array}$ & $\begin{array}{l}\text { Öğretmenin sunduğu } \\
\text { bilgi ile kök alma } \\
\text { işleminin anlamını } \\
\text { ilişsilendirir. }\end{array}$ \\
\hline & $\begin{array}{l}\text { Üslü ifadelerle ilişkilendirme } \\
\qquad 7^{n / m}=\sqrt[m]{a^{n}} \\
27^{x}=3 \text { denkleminin } \\
\text { çözümünden yararlanma }\end{array}$ & 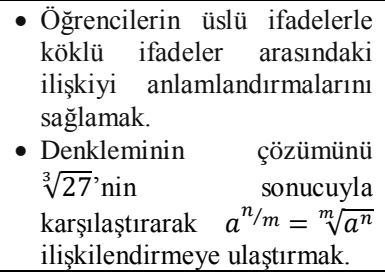 & $\begin{array}{l}\text { Üslü ifade içeren } \\
\text { denklemin çözümünden } \\
\text { yararlanarak ögrencilerin } \\
\text { üslü-köklü ifadeler } \\
\text { arasındaki ilişkiyi } \\
\text { anlamalarını sağlar. }\end{array}$ & $\begin{array}{c}\text { Ön bilgilerinden } \\
\text { yararlanarak üslü } \\
\text { ifadeleri içeren } \\
\text { denklemi çözer ve bu } \\
\text { denklem yardımıyla } \\
\text { üslü ifadeleri köklü } \\
\text { ifadelerle } \\
\text { ilişkilendirir. }\end{array}$ \\
\hline & $\begin{array}{l}\text { Soru sorma }\left(20^{\prime}\right) \\
\text { - } \sqrt{3^{3 x-3}}=\sqrt[3]{3^{4 x+2}} \text { eşitliğinde } \\
\text { x değeri kaçtır? } \\
\text { - } \sqrt[5]{(0,00243)^{x}}=0,09 \\
\text { eşitliğinde x'in değeri kaçtır? } \\
-\sqrt[5]{32^{x-1}}=8 \text { olduğuna göre } \\
\sqrt[x]{16} \text { işleminin sonucu kaçtır? }\end{array}$ & 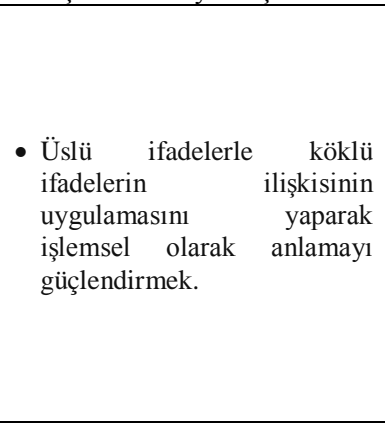 & $\begin{array}{c}\text { Öğrencilere sorular } \\
\text { sorduktan sonra } \\
\text { düşünmeleri ve } \\
\text { yanı̈lamaları için bekler, } \\
\text { ögrencilerin fikirlerini } \\
\text { dinleyerek hatalı çözüm } \\
\text { varsa onları dikkate alır } \\
\text { ve yanıtlar üzerine tüm } \\
\text { sınıfı tartışmaya teşvik } \\
\text { eder. }\end{array}$ & $\begin{array}{c}\text { Sorunun çözümünü } \\
\text { yapmak için üslü } \\
\text { ifadeleri içeren } \\
\text { denklem çözümlerine } \\
\text { ilişkin ön bilgilerini } \\
\text { kullanır, çözümünü } \\
\text { nedenleriyle açıklar } \\
\text { ve arkadaşlarının } \\
\text { çözümü ile } \\
\text { karşllaştırarak } \\
\text { tartı̧ma ortamına } \\
\text { aktif bir şekilde dahil } \\
\text { olur. }\end{array}$ \\
\hline 竝 & $\begin{array}{l}\frac{\text { Soru sorma }}{(12}\left(10^{\prime}\right) \\
\sqrt[12]{2^{13}} \text { ifadesini farklı şekilde } \\
\text { nasıl yazabilirsiniz? }\end{array}$ & $\begin{array}{l}\text { - Öğrencilerin köklü ifadelerin } \\
\text { anlamını öğrenip } \\
\text { öğrenmediklerini ortaya } \\
\text { çıkarmak ve ders boyunca } \\
\text { tartışlan konuları uygulayıp } \\
\text { uygulayamayacaklarını } \\
\text { değerlendirmek. }\end{array}$ & $\begin{array}{c}\text { Öğrencilere soruyu } \\
\text { sorarak düşünmeye teşvik } \\
\text { eder ve farklı düşünceleri } \\
\text { ortaya çıarmaya çalışır, } \\
\text { ögrencilerin ifadelerini } \\
\text { dikkate alır ve onların } \\
\text { fikirlerini değerlendirir. }\end{array}$ & $\begin{array}{c}\text { Öğrendikleri bilgileri } \\
\text { kullanarak ifadeyi } \\
\text { farklı şekillerde nasıl } \\
\text { yazacağını düşünür } \\
\text { ve düşüncelerini } \\
\text { nedenleriyle birlikte } \\
\text { açıklar. }\end{array}$ \\
\hline
\end{tabular}

